OPEN ACCESS

Edited by:

Francisco Jose Barba,

University of Valencia, Spain

Reviewed by:

António Manuel Jordão,

Instituto Politecnico de Viseu, Portugal

Ren-You Gan,

Shanghai Jiao Tong University, China

*Correspondence:

Colin E. Champ

champce@upmc.edu

Specialty section:

This article was submitted to Nutrition and Food Science

Technology,

a section of the journal

Frontiers in Nutrition

Received: 01 January 2019 Accepted: 27 March 2019

Published: 30 April 2019

Citation:

Champ CE and Kundu-Champ A (2019) Maximizing Polyphenol Content to Uncork the Relationship Between Wine and Cancer. Front. Nutr. 6:44. doi: 10.3389/fnut.2019.00044

\section{Maximizing Polyphenol Content to Uncork the Relationship Between Wine and Cancer}

\author{
Colin E. Champ ${ }^{1,2 *}$ and Anjali Kundu-Champ ${ }^{1}$ \\ ${ }^{1}$ Cancer Prevention Project, Pittsburgh, PA, United States, ${ }^{2}$ Department of Radiation Oncology, University of Pittsburgh \\ Medical Center, Pittsburgh, PA, United States
}

Studies have revealed conflicting results regarding the risk of cancer from alcohol consumption. Furthermore, some studies have suggested that wine may have benefits that separate it from other alcoholic beverages. As wine contains a significant amount of chemicals, specifically polyphenols like anthocyanins and proanthocyanidins (PA), that can affect cellular function and promote health, this hypothesis is reasonably supported by recent research. Polyphenols promote several anticancer cellular pathways, including xenobiotic metabolism, support of innate antioxidant production, and stimulation of phase I and II detoxification of carcinogens. However, the multitude of growing and production conditions of grapes, including temperature, water availability, soil type, maceration, and aging can result in a remarkably varying final product based on the available literature. Thus, we hypothesize that wines produced from grapes cultivated between steady daily temperatures at $15-25^{\circ} \mathrm{C}$ with moderate sun exposure from flowering to harvest, lower vine-water status, resulting either from lower precipitation, and irrigation practices or more permeable soil types, limitation of fertilizers, extended maceration, and aging in oak will impact the concentration of anthocyanins and PA in the finished wine and may have a differential impact on cancer. This higher concentration of polyphenols would, in theory, create a healthier wine, thus explaining the conflicting reports on the benefits or harms of wine.

Keywords: wine, cancer, phenolic, flavonoid content, radical oxygen species (ROS), biosynthesis of flavonoids

\section{INTRODUCTION}

With data emerging revealing the health benefits of a Mediterranean eating pattern, comprised of polyphenol-rich foods like olive oil and red wine, the impact of wine on overall health has been of great interest. Furthermore, according to the Organization of Vine an Wine (OIV), an intergovernmental organization overseeing the scientific and technical aspects of wine viticulture and viniculture, total global consumption of wine is staggering with nearly 645 million gallons consumed in 2017 alone (1). Wine is an important part of many cultures around the world, including Italy, Spain, and France, which are the world's largest producers, and in 2015, they collectively produced $48 \%$ of the world's total wine volume (2). In the United States, just over $50 \%$ of the population reports that they are routine consumers of alcohol (3). Since 1998, wine consumption in the United States has steadily increased, to an average consumption of 2.95 gallons/year/resident in 2016, reflecting a collective consumption of 3.6 billion total gallons of wine. While according to the World Health Organization $17 \%$ of alcohol consumed by Americans is wine, two thirds of alcohol consumption in European countries, such as Italy, is comprised of wine. 
The risks and benefits of moderate red wine and alcohol consumption remain controversial. Recent meta-analyses have produced mixed results, revealing small increases in breast cancer in women and colon cancer in men, and small decreases in thyroid, lung, and hematologic malignancies (4). The majority of studies reveal increased cancer with excessive alcohol exposure, especially for oropharyngeal and esophageal cancer. Yet, a recent analysis revealed a potential increase even with light alcohol consumption (5). Making conclusions from the available research is difficult, as nutritional population studies introduce variables that are difficult to account for and can influence findings, and populations consuming alcohol are heterogeneous (6). Metaanalyses can aid in estimating cancer risk, but are less able to reduce confounding. For instance, alcohol consumption is often linked to cigarette smoking, which is established to increase the risk of multiple other cancers (7). Furthermore, alcohol and tobacco smoke may have a synergistic effect on the development of cancer (8), and a large analysis of women revealed that alcohol-related risk of aerodigestive cancer was limited to those women who both smoked and consumed alcohol (9). Alcohol consumption is also linked with socioeconomic status and comorbid conditions, like anxiety and depression, further negatively impacting studies (10). Finally, other studies suggest no increased risk of cancer with alcohol usage at moderate levels $(<30 \mathrm{~g} /$ day), and additional risks in those who consume above this amount are confounded by obesity and poor folate status (11).

However, some feel as though moderate wine consumption may have a different physiologic impact when compared to other sources of alcohol. Further analyses of several studies assessing alcohol consumption and cancer reveal a lack of association between wine consumption and cancer (9), and others hint at a protective effect. For instance, the Copenhagen City Heart Study revealed that wine drinkers, as opposed to other alcoholic beverage drinkers, experienced a reduction in death from both coronary heart disease and cancer (12). This study and others have revealed a controversial J-shaped relationship between wine consumption and cancer: increased risk at no and high consumption. A recent meta-analysis of 111 unique cohort studies revealed a $7 \%$ increased risk of colon cancer for each 10 $\mathrm{g} /$ day increase in alcohol intake (13). However, a meta-analysis of eight case-control and nine cohort studies from the same year, including over 12,000 cases of colorectal cancer, revealed no relationship between wine consumption and colorectal cancer (14). Furthermore, studies have shown an association between improved survival after colorectal cancer diagnosis and prediagnosis wine consumption (15).

Several tangible mechanisms to describe a potential carcinogenic effect of alcohol exist. Ethanol in wine and other alcoholic drinks is metabolized by the liver via the enzyme alcohol dehydrogenase to form acetaldehyde. Ethanol is also metabolized to aldehyde via microbes within the gastrointestinal tract, which can also increase intestinal permeability (16). Acetaldehyde, a toxic carcinogen, is responsible for the typical hangover symptoms that occur after excessive alcohol intake. Furthermore, while ethanol itself does not appear to be carcinogenic, in vitro studies reveal that acetaldehyde can generate reactive oxygen species (ROS), damage both DNA and proteins, and produce cellular mutations (17). These mechanisms may explain both the increase in risk of aerodigestive cancer and alcohol consumption and the synergistic effect of smoking and alcohol. Additionally, alcohol consumption can affect serum hormonal levels and increase estrogen, potentially leading to an increased risk of breast and endometrial cancer (18).

However, to our knowledge, all studies assess quantity of ethanol consumption within alcoholic drink type subgroupings. Recent analyses in other food types reveal that the quality of foods, separate from quantity, can elicit distinct physiologic and metabolic responses. For instance, feeding animals their natural food for nourishment while allowing them to graze can result in significantly different fatty acid profiles and anti-inflammatory content that can result in measurable differences within humans after their consumption (19). In wine production, growing conditions, viticultural practice, and maceration/fermentation techniques can have a significant impact upon the resulting wine, producing a product that varies considerably in chemical composition. Thus, it is reasonable to hypothesize that a similar effect may be seen in wine drinkers. This article proposes that several factors should be taken into consideration in future studies that assess the relationship between wine and cancer.

\section{THE POTENTIAL BENEFITS OF MODERATE WINE CONSUMPTION AND IMPACT OF POLYPHENOLS}

Wine is a water-dominant solution containing a variety of chemical compounds, inclusive of aldehydes, esters, ketones, lipids, minerals, organic acids, phenolics, soluble proteins, sugars, and vitamins. In regards to the potential health benefits of wine, phenolics are considered the most important phytochemicals and have been given the greatest attention for their impact as an anti-oxidant constituent of wine, and for their ability to act as a free radical terminator and metal chelator (20). They possess many biological activities and health-promoting benefits. According to molecular structures, phenolic compounds exist in four major classifications: one phenolic ring (benzoic and cinnamic acids), two phenolic rings (stilbenes), three phenolic rings (anthocyanins, flavanols, and flavan-3-ols), and more complex ring structures (ellagic acids), the latter of which are found either in the Muscadine grape variety or more often are imparted on wines aged in oak (21-23). Flavonoids are the most dominant phenolics in a wine and come in the threering molecular structures-flavanols, anthocyanins, flavan-3-ols, and the oligomeric or polymeric condensed tannins, known as proanthocyanidins (PA), which are felt to be responsible for the antioxidant benefits from tea, fruit, and vegetable consumption $(24,25)$. The non-flavonoids present in three major types including hydroxycinnamic acids, stilbenoids, and phenolic acids and will not be the focus of this work, with the exception of vanillin, an aldehyde most prominent in the lignin structure of oak barrels (Figure 1).

Researchers have suggested that perhaps this combination of alcohol with certain substances or chemicals in wine may provide 


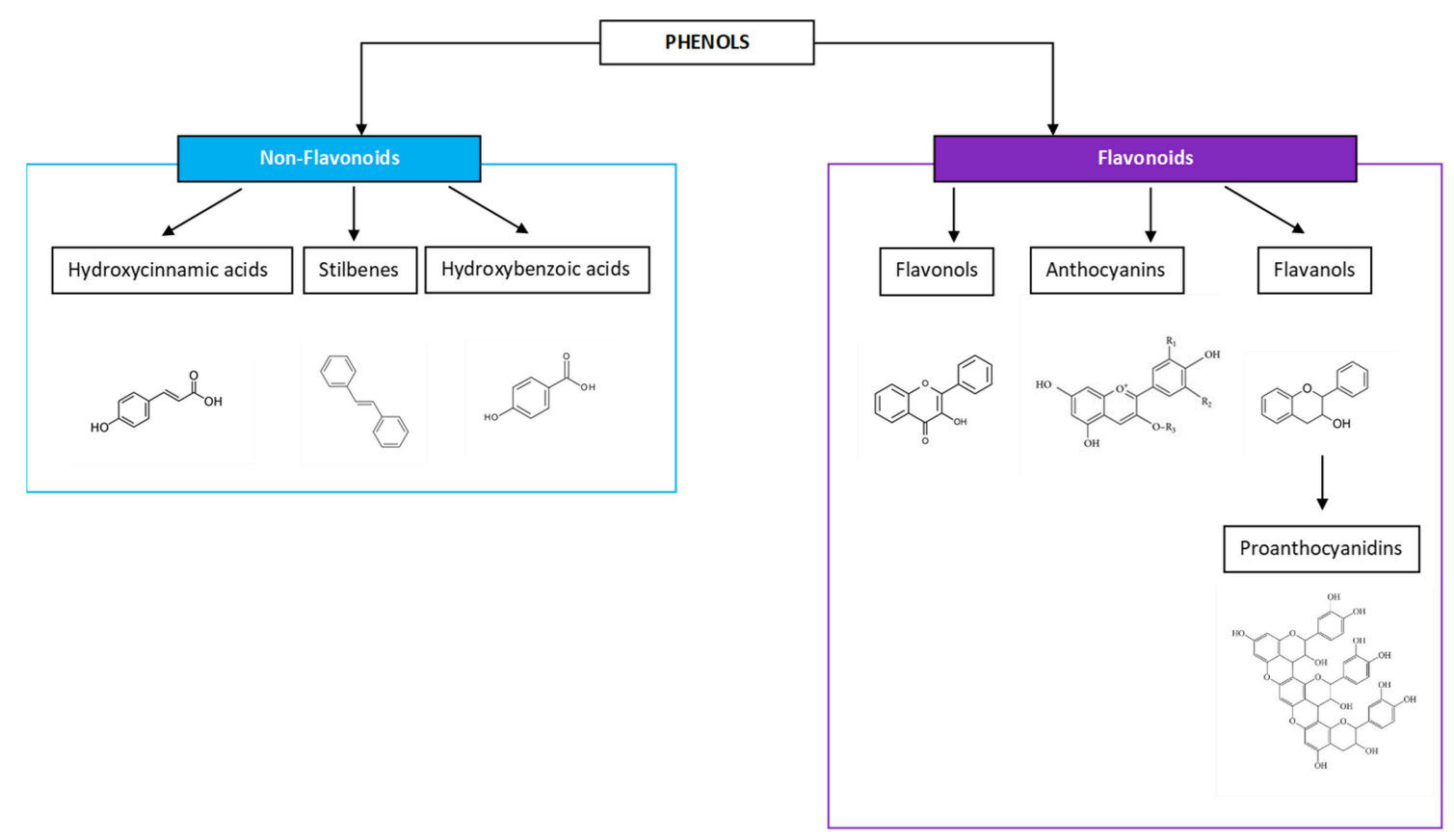

FIGURE 1 | Phenols include non-flavonoid and flavonoid compounds, both of which are gaining more interest for the perceived health benefits.

a benefit and explain the reduction in all-cause mortality (12). Preclinical data have revealed that these chemicals, and other pro-oxidants and antioxidants present in red wine in particular, may induce apoptosis in cancer cells (26). Furthermore, the consumption of red wine has a pro-oxidant effect that promotes the upregulation of human cellular antioxidant defense mechanisms, increasing serum antioxidant levels in humans, independent of vitamin $\mathrm{C}$ and carotenoids, similar to other phenolic-containing foods like strawberries and spinach (27, 28). These changes suggest the ability to offset potentially carcinogenic damage from ROS. In vitro and in vivo studies reveal a protective effect of wine polyphenols against oxidation and DNA damage from irradiation and hydrogen peroxide (29), animal studies reveal a reduction in DNA oxidative damage within the rat colonic mucosa after exposure to polyphenols and PA from wine (30), and human studies reveal increased serum total antioxidant status and decreased plasma glutathione and malondialdehyde after the consumption of wine, indicating a decrease in oxidative stress (31).

Recent studies reveal that polyphenols work via several mechanisms to promote anticancer cellular pathways. These pathways include xenobiotic metabolism, support of innate antioxidant production, and stimulation of phase I and II detoxification of carcinogens. These pathways are not necessarily activated via endogenous antioxidant properties of these chemicals, but rather via their pro-oxidant pathways that stress normal cells to activate nuclear factor erythroid 2-related factor 2 (Nrf2) and the human antioxidant response system (32). Nrf2 then triggers a plethora of genes that increase antioxidant production, reduce oxidative stress and oxidative damage, and activate the detoxification of potentially harmful chemicals (33).

This response is consistent with the role of polyphenols in grapes and other fruits and vegetables, as they serve as defense chemicals that are toxic to potential predators, including insects, animals, and microbials. When humans encounter these polyphenols, and other similar chemicals, these toxic effects do not occur, but rather the potential chemical threat elicits a cellular response leading to several chemopreventive changes. For instance, animal studies have revealed potential anticarcinogenic and chemopreventive properties of the stilbene, resveratrol, via its activated phase II drug-metabolizing enzymes, inducing anti-inflammatory cellular function, and promoting antioxidant production (34). While these benefits are compelling, it is important to note that changes in polyphenol content in wine impact taste profile and sensorial characteristics of the wine, and the effect of this modification needs to be considered alongside consumer preference for various attributes of sugar, acid, and phenolic qualities of finished wine.

Bioavailability studies are generally difficult in practice, and thus limited in number, but reveal that polyphenols are absorbed via the lining of the intestines after modification by the epithelial cells in the small intestines and microflora within the colon (35). This process is variable, but can alter polyphenol content and bioavailability, before passage to the liver and entrance into the blood stream. While polyphenol structure and potency may be altered throughout the absorption process, studies reveal a subsequent increase in total plasma antioxidant status, and this is generally felt to be a direct result of the effect of the consumption of polyphenols. For instance, a study in healthy males revealed a 
significant loss in the expected rise of plasma antioxidant capacity after the consumption of phenol-stripped red wine (36). Red wine polyphenols have also been independently found to mediate the vascular effects of red wine consumption in humans, further supporting their ability to be absorbed (37). Lastly, urinary levels of 4-O-methylgallic acid, which are markers of phenolic acid absorption, are increased in humans after the consumption of red wine, and this absorption has been shown to offset lipid peroxidation in smokers (38).

Finally, chemicals released into the wine from wood during the aging process can significantly impact the chemical composition of the final product. For instance, Acutissimin A, a flavano-ellagitannin found in oak, can inhibit DNA topoisomerase II, a target for cancer (39). Furthermore, oak used for aging contains lignans, which are dimeric polyphenols exhibiting low estrogenic properties (40). Lignans are also present in tea, vegetables, and coffee, and have been shown to improve human health via several mechanisms. Lignans are metabolized by intestinal bacteria, promoting a healthy microflora (41). Data, however, are mixed, and some epidemiologic studies have suggested a potential protective effect in regards to breast cancer (42). While estrogenic themselves, lignans have been shown to reduce the production of estrogen, thus explaining this potential protective effect. In addition, a diet high in lignans through wine consumption has been associated with a reduced risk of the premalignant condition, Barrett's esophagus, and esophageal cancer $(43,44)$.

Here we investigate the impact of several known viticultural practices and the effect they have on synthesis of two critical phenols-anthocyanin and PA-in wine, postulating the importance of these elements and their antioxidant properties on human health, following consumption. Furthermore, we consider the environmental and viticultural processes that can increase their volume in finished wine.

\section{ANTHOCYANINS AND PROANTHOCYANIDINS}

Anthocyanins and proanthocyanidins are secondary metabolites produced within the skins, seeds, and stems of grapes through the phenylpropanoid pathway and downstream flavonoid biosynthesis. These phenolic chemicals are produced as defensive and protective chemicals in response to environmental stresses, changing growing conditions, and plant predators, including herbivores and microbial and fungal threats. Other potential threats, including metals in the soil, can activate the production of both (45). Furthermore, they are also produced in response to ROS, and accordingly, superoxide radical scavenging activity correlates with polyphenol levels in the grapes (46). Anthocyanins are generally located along the epidermal surfaces of the growing plant, including the berry skin, and plant stems and leaves. Through their pigmentation properties, they serve as a protective barrier from excessive sun exposure, much like melanin in human skin. Anthocyanin accumulation within the berry typically begins at the onset of ripening, known as véraison. Anthocyanins represent a collection of several individual chemical constituents that have individual production peaks throughout the growing process, beginning with dehydroxylated glucosides (cyanidin, peonidin) followed by trihydroxylated anthocyanins (delphinidin, petunidin, malvidin) (47).

PA and flavonol compounds are generally found in the berry seeds and skins, as well as the stems. They follow a different biochemical and phonologic trajectory from anthocyanins (Figure 2), with their synthesis occurring at fruit set, between flowering and véraison; thereafter, oxidation and metabolism through ripening decreases the amount of PA until harvest $(49,50)$. These chemicals are a flavonoid plant secondary metabolite, functioning to deter herbivores and are characterized by antifungal properties and the deterrence of pathogens. They can also react with anthocyanins to stabilize them and aid in pigmentation (51). (+)-Catechin, (-)-epicatechin, and epigallocathechin flavan-3-ols are synthesized through the same flavonoid pathway as anthocyanins, but via a different regulation and enzymatic step (52), resulting in PA.

The concentration and composition of phenols, including anthocyanins and PA, is largely, although not exclusively, based on the grape cultivar, or variety (53). For instance, the presence of PA in Syrah, Cabernet Sauvignon, and Merlot is markedly higher than the concentration in Gamay, Pinot Noir, and Zinfandel (54), while Syrah, Malbec, and Cabernet Sauvignon have generally high concentrations of antioxidant-promoting phenols (55). The Tannat grape varietal has exceedingly high PA and total anthocyanin content, producing a firm tasting, full-bodied wine with tannic structure $(56,57)$. In addition, environment and viticultural practice, along with harvest date, are other critical factors affecting accumulation of both anthocyanins and PA, along with acid and sugar profiles desired by consumers, and these factors in combination differentiate finished wine products and their related antioxidant capability (53).

Evidence is building to propose that elements of the flavonoids contribute to important bioactivities such as antioxidant, cardioprotective, anti-inflammation, anti-cancer and antiaging mechanisms, garnering more interest and scientific evaluation (Table 1) (97, 98). For instance, anthocyanin isolates and anthocyanin-rich mixtures of bioflavonoids may provide protection from DNA cleavage, estrogenic activity (altering development of hormone-dependent disease symptoms), enzyme inhibition, boosting production of cytokines and regulating immune responses, anti-inflammatory activity, lipid peroxidation, decreasing vascular permeability, and membrane strengthening (99). Meanwhile PA have been shown to suppress free radicals and potentiate other antioxidants such as vitamin $\mathrm{C}$ and vitamin $\mathrm{E}$, while also strengthening capillaries in the mitigation of chronic venous insufficiency, lowering blood pressure, slowing the progression of diabetic retinopathy, and increasing the amount of UV rays necessary to cause sunburn, reducing photocarcinogenesis (100). PA, predominantly those found in grape seeds, have also been shown to have anti-carcinogenic activity on tumor models related to prostate, metastatic breast and colorectal cancer $(101,102)$. 


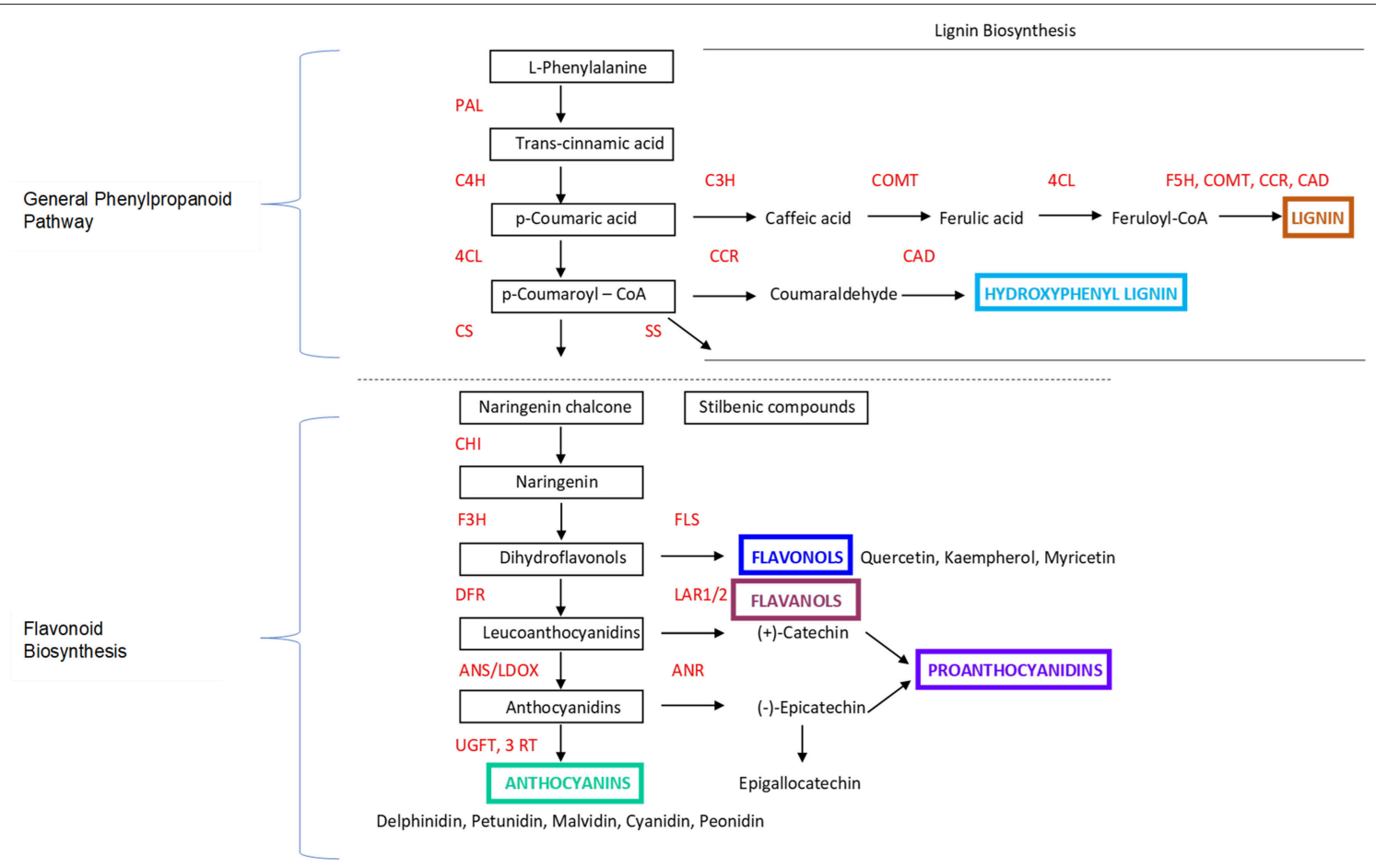

FIGURE 2 | Marè et al. (48). Overview and simplification focusing on the key steps of the Phenylpropanoid Pathway and Flavonoid Biosynthesis in Grapes and Plants. PAL, phenylalanine ammonia-lyase; C4H, cinnamate 4-hydroxylase; 4CL, 4-coumarate-CoA ligase; CS, Chalcone Synthase; SS, Stilbene Synthase; CHI, chalcone isomerase; F3H, flavanone 3-hydroxylase; FLS, flavonol synthase; DFR, dihydroflavonol-4-reductase; LAR1/2, leucoanthocyanidin reductase 1/2; ANS/LDOX, anthocyanidin synthase/leucoanthocyanidin dioxygenase; ANR, anthocyanidin reductase; UFGT, UDP-glucose:flavonoid-3-O-glucosyltransferase; 3RT, anthocyanidin 3-glucoside rhamnosyltransferase. Additional information provided related to Lignin Biosynthesis. C3H, p-coumarate 3-hydroxylase; COMT, Caffeoyl CoA O-methyltransferase; 4CL, 4-coumarate:CoA ligase; F5H, COMT, CCR, CAD, Ferulate 5-hydroxylase; CCR, Cinnamoyl-CoA reductase; CAD, Cinnamyl alcohol dehydrogenase.

\section{ENVIRONMENTAL CONDITIONS}

"Terroir" is the French term used to define the geographical and environmental position of grapes. Terroir consists of several environmental factors that can influence its phenotypic expression, including geography, geology, and vertical zonality or altitude in which a vine is grown (103). Terroir has a major influence on the taste profile and typicity of the wine, but more importantly for its effect on grape composition, including phenolic content, whereby it creates a differential wine that can influence health. The following are several aspects of terroir considered in their influence on anthocyanin and PA accumulation.

\section{Temperature and Sun Exposure}

Temperature and sun exposure are significant factors in grape growth and finished wine. They are generally considered together as they have shared responsibility in activation of the phenylpropanoid pathway and synthesis of anthocyanins and PA. Both appear to result in a similar effect on plant biosynthesis of these chemicals and separating the effect of sunshine vs. warmth is difficult, except in in situ studies (104-106).

Temperature is one of the primary elements of terroir. While grapevines are grown in a wide variety of climates, the major wine-growing regions in the northern hemisphere require adequate warmth without excessive heat, and thus are located between the 35th-50th parallels and in the southern hemisphere, are located between the 30th-45th parallels. The Mediterranean climate regions, known for their warm and dry summers and cool and wet winters, meet similar criteria, are often considered to be the optimal environment for viticulture, whereas, tropical climates do not serve as compatible environments for grapevine growing due to excessive heat, precipitation, and humidity (104).

Moderate temperatures during the night and day (15$25^{\circ} \mathrm{C}$, respectively) promote the biosynthesis and accumulation of anthocyanins in the skins of the grape berries, while temperatures exceeding $35^{\circ} \mathrm{C}$ can decrease the accumulation of these chemicals through both the inhibition of biosynthesis pathways (107). and via the degradation of anthocyanins in grape skins $(108,109)$. Elevated and excessive temperatures can shorten phenological stages and impact bud break, flowering, véraison, ripening, maturity, and harvest, and affect wine quality. Elevated temperatures at night appear to affect anthocyanin accumulation and profile via the inhibition of anthocyanin mRNA transcription (110), but only during the véraison period (111). Conversely, low nightly temperature can enhance anthocyanin production (112).

Sunlight exposure is influential in the level of anthocyanins present in grape berry skins, as ultraviolet light is a fundamental 
TABLE 1 | Selected phenolics common in red wines and their associated biological activities and health-inducing effects.

\begin{tabular}{|c|c|c|}
\hline Phenol class & Sample biological activities and health protective attributes & References \\
\hline \multicolumn{3}{|l|}{ NON-FLAVONOIDS } \\
\hline Hydroxycinnamic Acids & $\begin{array}{l}\text { Prevention of oxidative stress, diabetes, insulin resistance, body weight gain, dyslipidemia, cardiovascular disease, } \\
\text { renal disfunction } \\
\text { Enhanced potency as an anti-inflammatory agent } \\
\text { Improvement of liver function }\end{array}$ & $(58,59)$ \\
\hline Stilbenoids & $\begin{array}{l}\text { Cancer treatment and prevention, through mechanisms of apoptosis, inhibition of angiogenesis and proliferation of } \\
\text { multiple cancer cell lines } \\
\text { Neuroprotection, through reduction of amyloid plaques, cerebral infarct volume, neuronal ROS, and inhibition of } \\
\text { cholinesterases } \\
\text { Depigmentation, through decreased melanin production and inhibition of tyrosinase activity } \\
\text { Protection against cardiomyocyte and cardiac hypertrophy, through activation of AMPK and upregulation of eNOS } \\
\text { Blood Pressure Regulation, through lowering of systolic blood pressure at high doses } \\
\text { Reduced Platelet Aggregation, through inhibition of COX enzymes } \\
\text { Reduction in Obesity, through inhibition of lipogenesis, increased lipolysis, activation of AMPK, SIRT and PGC-1 } \alpha \\
\text { Management of Diabetes, through enhanced insulin sensitivity, increased AMPK-dependent microbial biogenesis, and } \\
\text { increased glucose uptake } \\
\text { Defense against Atherosclerosis, through reduction in oxidative stress markers and inhibition of LDL in endothelial cells } \\
\text { Protection against UV radiation resulting in reduced DNA damage, skin damage and cancer } \\
\text { Protection against Ischemia-reperfusion injury, through increased antioxidant enzymes and reduced oxidative stress }\end{array}$ & $(60-64)$ \\
\hline Hydrobenzoic Acids & $\begin{array}{l}\text { Antimicrobial properties } \\
\text { Amelioration of cardiovascular problems such as hypertension, atherosclerosis, and dyslipidemia } \\
\text { Neuroprotection and anti-inflammatory effects providing defense again neurogenerative diseases of Alzheimer's and } \\
\text { Parkinson's diseases and amyotrophic lateral sclerosis (ALS) }\end{array}$ & $(65-67)$ \\
\hline \multicolumn{3}{|l|}{ FLAVONOIDS } \\
\hline \multicolumn{3}{|l|}{ Flavonols } \\
\hline Quercetin & $\begin{array}{l}\text { Induction of apoptosis, which has been particularly effective in decreasing growth of brain, liver and colon cancers } \\
\text { Reduction of coronary artery disease due to increase flow-mediated dilation of major arteries } \\
\text { Modulation of inflammation by way of COX and lipoxygenase inhibition } \\
\text { Reduction of oxidative damage to lymphocytes and neurovascular structures which inhibits damage to neurons and } \\
\text { protects against neurodegenerative disorders } \\
\text { Gastroprotective effect by way of inhibition of gastric acid secretion } \\
\text { Anti-allergic effect, through inhibition of release of histamine from mast cells }\end{array}$ & $(68-70)$ \\
\hline Myricetin & $\begin{array}{l}\text { Cytotoxicity in many cancer cell lines including hepatic, skin, pancreatic, and colon cancers } \\
\text { Anti-inflammatory effects on periodontitis and rheumatoid arthritis, through various cellular mechanisms } \\
\text { Protective effects against Parkinson's Disease and Alzheimer's Disease } \\
\text { Vascularprotective effect, through alteration of vascular disease-related genes, including HIRA, HDAC9, HIF1A and } \\
\text { RTN3 } \\
\text { Management of non-insulin-dependent diabetes, by stimulating the uptake of glucose without functional } \\
\text { insulin receptors }\end{array}$ & $(77-79)$ \\
\hline \multicolumn{3}{|l|}{ Anthocyanins } \\
\hline Delphinidin & $\begin{array}{l}\text { Inhibition of EGFR and downstream signaling cascades, most notably in vulvar carcinoma } \\
\text { Decrease in cell viability, induction of apoptosis, cleavage of PARP, activation of caspases-3,-8, and-9, increase in } \\
\text { Bax with concurrent decrease in Bcl-2 protein, and cell cycle arrest in G2/M phase, in colon cancer } \\
\text { Mediated suppression of osteoclast formation, resulting in prevention of bone loss } \\
\text { Increase in insulin secretion }\end{array}$ & (80-83) \\
\hline Petunidin & $\begin{array}{l}\text { Inhibition of breast cancer and liver cancer cell growth, via inhibitory behavior } \\
\text { Increase in insulin secretion } \\
\text { Inhibition of alpha-glucosidase and lipase in alleviation of diabetes }\end{array}$ & $(83,84)$ \\
\hline Malvidin & $\begin{array}{l}\text { Inhibition of various tumor cell lines including promyelocytic/monocytic leukemia cells, colon cancer cells, and gastric } \\
\text { adenocarcinoma cells } \\
\text { Increase in insulin secretion } \\
\text { Antihypertensive activity by inhibition of angiotensin I-converting enzyme and anti-inflammatory effect by blocking } \\
\text { NF-kB pathway } \\
\text { Counteractive effect on oxidative stress in neuronal cells }\end{array}$ & $(83,85,86)$ \\
\hline
\end{tabular}


TABLE 1 | Continued

\begin{tabular}{|c|c|c|}
\hline Phenol class & Sample biological activities and health protective attributes & References \\
\hline Cyanidin & $\begin{array}{l}\text { Inhibition of EGFR and downstream signaling cascades, most notably in vulva carcinoma } \\
\text { Induction of cancer cell apoptosis, reduced oxidative damage to DNA, inhibited cell growth and decreased cancer cell } \\
\text { proliferation, notably in leukemia, lung, colon, skin and prostate cancer } \\
\text { Prevention of Type II Diabetes through enhanced adiponectin and leptin secretion } \\
\text { Preventative effect on Type II Diabetes through increased phosphorylation of AMPK } \alpha \text { at Thr172 in rat adipose cells }\end{array}$ & $(80,87)$ \\
\hline Peonidin & $\begin{array}{l}\text { Chemopreventative and anti-inflammatory effect on inhibition of TPA-induced COX-2 expression, and decreased } \\
\text { TPA-induced neoplastic transformation and blocked TPA-induced phosphorylation of extracellular signal-related } \\
\text { kinases in breast cancer cells }\end{array}$ & (88) \\
\hline \multicolumn{3}{|l|}{ Flavanols } \\
\hline (+)-Catechin & $\begin{array}{l}\text { Mediation in cardiovascular health via mechanisms of blood pressure reduction, flow-mediated vasodilation, and } \\
\text { atherosclerosis attenuation } \\
\text { Induction of antioxidative and neuronal anti-inflammatory effects in Alzheimer's Disease }\end{array}$ & $(89,90)$ \\
\hline (-)-Epicatechin & $\begin{array}{l}\text { Improvement of endothelium-dependent flow-mediated dilation of the brachial artery important for vascular health } \\
\text { Attenuation of atherosclerosis via modulation of NF-кB activity }\end{array}$ & (91) \\
\hline $\begin{array}{l}\text { Proanthocyanidins } \\
\text { (oligomeric/polymeric) }\end{array}$ & $\begin{array}{l}\text { Anti-tumor activity in PC-3 prostate cancer cell lines, through cell cycle arrest, and activation of caspase-3 } \\
\text { Inhibition of NF-kB and downstream cascades in human epidermoid carcinoma } \\
\text { Reduction in proliferation, increased apoptosis, cell cycle arrest and modulation of key genes beneficially regulates } \\
\text { invasion and metastasis for prostate and photocarcinogenesis } \\
\text { Protection against oxidative stress and degenerative diseases including cardiovascular dysfunctions, acute and chronic } \\
\text { stress, gastrointestinal distress, neurological disorders, pancreatitis, various stages of neoplastic processes, and } \\
\text { carcinogenesis including detoxification of carcinogenic metabolites } \\
\text { Reduction in hypertension via inhibition of the reactive oxygen species/mitogen-activated protein kinase pathway via } \\
\text { restraining the release of ET-1 } \\
\text { Inhibition of lipid peroxidation, platelet aggregation, capillary permeability and fragility, and to affect enzyme systems } \\
\text { including phospholipase A2, cyclooxygenase, and lipoxygenase }\end{array}$ & $(92-96)$ \\
\hline
\end{tabular}

prerequisite for color formation in grapes and other plants (109). Anthocyanins are produced as a method to provide protection against solar radiation and serve to protect photosynthetic tissues from ultraviolet damage, absorbing blue-green, and ultraviolet light. Transcription and expression of genes such as UDPglucoside: flavonoid glucosyltransferase (UGFT) is induced by light, which has the net effect on the cellular mechanisms aiding in anthocyanin synthesis (113). Many studies evaluate the sunlight exposure and microclimate of various cultivars, whereby grape berries move through their phenologic phases under naturally occurring conditions, with application of berry cluster thinning, removal of basal leaves, and with canopy shading regimens (114). This manipulation of the microclimate, of the localized environment created naturally by the grapevine itself, has garnered great interest from a viticultural perspective, as intentional adjustments on the plant itself can regulate sun exposure and optimize anthocyanin production.

Studies conducted in merlot and carmenere berries and skins conclude that temperature has a non-significant or secondary effect on PA accumulation; although there is a direct relationship between berry mass and PA content, along with a direct relationship between temperature on berry growth (115). Other studies reveal a complex relationship between temperature and PA production that relies on multiple factors, including season, vine age, and grape type, among others (52). Further research is needed to elucidate this relationship.

While temperature has a poorly understood or non-significant effect on PA, sun exposure has a more recognizable impact on PA accumulation, notably signaling an increase in PA production in grape skins from flowering to véraison (52). A number of studies have been conducted on various cultivars including Merlot, Shiraz, and Pinot Noir, which have yielded somewhat conflicting results. Lee et al. revealed no significant difference in PA content of light-excluded and non-light-excluded Merlot samples, consistent with the findings of Downey et al. (116). However, (117) found a result of higher PA concentration in light-excluded Shiraz, while Cortell found that PA were lower in light-excluded Pinot Noir. Several reasons explain these conflicting results, namely, analytical method, variations in growing vineyards and notably cultivar, as is elucidated by Asproudi et al. (118) and Lee (119).

\section{Water Stress}

Plant growth and production has historically been associated with geographies where rainfall is sufficiently supportive for growth, while avoiding excessive rain and overwatering. Along these lines, intentional water restriction can have significant effects on the chemical profile of grape varietals. Targeted water deficits and regulated irrigation can provide the grape vine with water stress and maximize the production and concentration of anthocyanins and PA, and this effect is more pronounced in red in comparison with white cultivars, which naturally have lower anthocyanins and PA volumes (120). Precipitation along with water deficits, both their amount and timing (phenological stage), affect vegetative growth, berry growth, fruit quality, titratable acidity/malic acid, phenolics, and yield.

While precipitation, in moderation, is essential for most plant life, extended periods of rainfall are specifically associated with 
increased risk of diseases in $V$. vinifera, including downy mildew and botrytis rots (121). Further, direct rain damage to ripening berries results from rapid swelling from excess water intake, which increases osmotic pressure and can hinder biosynthesis of phenols (122). Temperatures up to $25^{\circ} \mathrm{C}$ accompanied by low rainfall, induce the maximal concentration of polyphenols in grapes (123). Supporting these findings, research has shown that when Cabernet Sauvignon experiences lower rainfall in its dormant stage, vines produce looser clusters, heavier berry skins and higher total soluble solids (124). In comparing two vintages, the drier vintage had lower measurable vine water status and lower Nitrogen levels in the soil, and it had a higher resulting concentration of anthocyanins.

Thermal and water stresses can also synergistically enhance grape polyphenol production, while higher irrigation dose (patterns of watering and re-watering) reduces phenolic content of finished wines (123). These results have been substantiated by several studies, which found specifically that water stress during pre-véraison (onset of ripening) stages has the ability to ignite metabolic changes within the grape that remain after re-watering, activating, and altering transcripts and metabolites involved in phenyl propanoid, isoprenoid, carotenoid, amino acid, and fatty acid metabolism (120). Moreover, lower vine water status results in smaller berries, but thicker and heavier skin weights, correlating to higher anthocyanin concentrations, illustrating the sensitivity of anthocyanin biosynthesis to osmotic stress (124). Studies in Merlot, Shiraz, and Cabernet Sauvignon cultivars all reveal a correlation between water deficit and increased expression of genes responsible for anthocyanin synthesis, and the resulting accumulation of anythocyanins $(125,126)$. When assessing four stages of phenologic development, including pea size, véraison, maturation and full maturation, researchers observed that under sustained deficit irrigation, PA increased (127). Furthermore, at full maturation, anthocyanin and PA content is significantly higher in the skins and seeds, respectively, treated with both sustained and regulated deficit irrigation as compared with non-irrigated berries (128).

\section{Soil Type and Fertilizers}

Vineyard geology-bedrock and overlying soils-is widely considered to help explain the typicity of wine from a particular region. Soil types may have an impact on the composition of finished wines, just as soil has an impact on any agricultural product due to mineral uptake. Grapes are vinified in a variety of soil conditions including igneous, metamorphic, sedimentary and textured soils, all with varying degrees of density, penetrability, and mineral content. Expectedly, soil type influences water content and irrigation as previously discussed, along with ground temperature, thus influencing grape growing and the resulting agricultural product, including wine. However, to our knowledge, limited attention has been given to soil type as a standalone factor-perhaps because it is difficult to isolate and control this in the presence of $\mathrm{pH}$ and mineral compositionand any independent effect it may have on phenolic compounds in grape berries.

An assessment of Cabernet Sauvignon grown in the Helan Mountain range in Ningxia, China, found that grapes grown in eolian soil (loess) and sierozem had increased anthocyanins and more phenols, as compared with irrigation silting soil (129). Sierozem soils are characterized by good physiologic properties, high biological activity and fertility resulting in high yields. Eolian soil, which consists of sand and sediment, performs similarly to rocky soils by limiting water retention given the ease with which water drains through the soil crevices.

The application of fertilizer can influence the final wine product and its chemical composition. Fertilization is most often utilized when the soil itself cannot provide sufficient nutrients to the plant to improve or maximize yield. In $V$. Vinifera the most common fertilizer additives in vineyards include treatments with nitrogen, potassium, and phosphate. The former two have been more extensively studied and have been demonstrated to reduce the color of grapes under higher application doses (130-132).

Nitrogen, in combination with other environmental influences, can lead to excessive plant growth, known as vigor, but can decrease the overall yield of berries (133). Grapevines which exhibit excessive vigor have excessive shoots, triggering an imbalance between the relative amount of vegetation and fruit, with vegetation prevailing. Excessive vigor leads to shaded fruits, which results in reduced activity of the photosensitive steps and MYB-family gene regulatory processes involved in the flavonoid biosynthesis occurring in the phenylalanine pathway, resulting in lower anthocyanin synthesis (130). Essentially, nitrogen-induced grapevine vigor can act as a barrier to reduce the amount of light in contact with the berries within the canopy, reducing the activity of photosensitive enzymes that regulate the phenylpropanoid pathway and limit production of phenolic compounds, namely anthocyanins (134). Importantly, nitrogen acts in different ways in different soil types. In general, in soils with lower organic matter and/or nitrogen, low nitrogen stress can enhance the production of anthocyanins (135).

Potassium plays a crucial role in biotic and abiotic stress response, plant physiology and biochemical processes such as photosynthesis, osmoregulation and enzyme activation (136). In grape berries, potassium is found in high concentrations when measured at harvest, accounting for nearly $80 \%$ of all the cations within a grape berry (137). Grapes and other plants produce potassium as a response to several stresses, including water stress and insect predators. Low potassium, or potassium stress, can result in the accumulation of ROS within the plant, which prompts the production of antioxidant defense mechanisms and polyphenols to scavenge free radicals, leaving them more acclimated for enhanced survival (138). The application of potassium in soil decreases insect infestation or other pathogenic attack, encouraging a strong cell wall and stimulating phenol production to reduce vulnerability and prevent further infection $(139,140)$. In the grape berries, it also aids in the balance of $\mathrm{pH}$ and acidity in finished wine. However, like nitrogen, concentration of potassium varies with soil type and its chemical and physical properties. Soils naturally rich in potassium, such as is the case in many Australian wine regions, often require manipulation to produce artificial potassium stress $(141,142)$.

Metals present in the soil can impart toxicity to the growing vines and stress the grape plant, prompting the 
production of antioxidant metabolites and polyphenols within the plant (143). Presence of $\mathrm{Sr}, \mathrm{Mn}, \mathrm{Si}$, and $\mathrm{Ph}$ content in soil was shown to lead to higher concentration of antioxidants in grapes (45). Polyphenols aid in plant defense of potentially toxic metals by acting as chelators, and freeradical-induced stress via peroxidases enhances metal chelation, linking the multiple defense mechanisms of the growing grape vine (144).

Biostimulants should also be briefly addressed, due to their impact on grape growth. They are defined as substances able to alter physiologic plant processes that result in benefits in enhanced nutrient uptake, growth, development, yield and response to abiotic stress which improve quality (145). Several categories of biostimulants exist, including, bacteria, fungi, seaweeds, higher plants, animals and humate-containing raw materials, among others (146). Biostimulants can be introduced via foliar application to the grapevine and have been shown to positively affect phenylalanine ammonia lyase activity and gene expression within the phenylpropanoid pathway, resulting in greater primary and secondary metabolism of phenolic compounds $(147,148)$.

Overall, small amounts of nutrients are required within the soil for optimal grape growth and maturation. However, excessive nutrients, much like excessive water and heat, can hinder anthocyanin and phenolic production by alleviating required plant stress. Grape vines that are stressed with low, but adequate levels of nutrients and minerals appear to produce the largest accumulation of anthocyanins and phenolic chemicals. Fortunately, through viticultural and field practice, winemakers can adjust and regulate mineral elements which can influence the production of these phenols.

\section{Maceration and Fermentation}

Berry maturation at harvest, and the concentration of anthocyanins and PA can influence the final wine profile, in combination with extractability and stability through maceration and fermentation. Maceration is the process whereby the crushed grape, skins, seeds, and even stems remain in a vessel and are given adequate time for fermentation. Maceration is divided into three stages: pre-fermentation, fermentation, and post-fermentation. During the process, the phenolic materials of the grape-including anthocyanins and PA, and other phenolsare leached from the grape skins, seeds, and stems into the must. Of all aspects of grape growth and wine production, maceration has the most significant influence on anthocyanin and PA content of the wine. Interestingly, while viticultural methods can increase or decrease anthocyanin, PA and other phenolic volumes, most winemakers rely heavily on maceration to make corrections or adjustments to their finished wine product. Extraction of phenols from the must is dependent on time of contact, temperature of maceration, and ethanol levels during fermentation $(53,149)$.

Maceration is a method of condensing and concentrating the volume of phenols in wine and is most commonly associated with red wine. Red wine derives its darker red color from phenolic and pigmented chemicals leached from the grape parts. White wine maceration is considerably shorter than red wine, limiting exposure and contact with the skin, seeds and stems, and thus leaves an un-pigmented wine $(150,151)$. Though, "orange wines" or skin-contact whites are beginning to come into wider production, namely in the Veneto Region of Italy, and also in Slovenia.

Anthocyanins are found mostly in the skin of grapes, imparting them with their blue, purple, and red color. When they are crushed and left to ferment in the winemaking vats, in general, the longer the juice is exposed to the skins and seeds, the more color is imparted on the wine due to chemical leaching (152). Anthocyanin extraction is in many cases considered easier than the extraction of PA during the maceration process (153). Several studies have shown that between days 3and 5 of maceration is when the majority of anthocyanins are diffused, inherently because of the water-soluble nature and accessible epidermal location of anthocyanins (154). Conversely, maceration times exceeding 20 days can reduce the volume of anthocyanins due to several mechanisms, including their absorption by yeast and also the rising level of ethanol $(155,156)$. However, PA and other phenolics continue to be secreted after this point (157).

PA concentration and extractability is greatly influenced by the cultivar (158). Skin PA are extracted more rapidly and readily than seed PA with studies revealing that two to three or more weeks of maceration and contact time result in the highest levels of PA extraction (157). Skin PA extraction reaches a plateau prior to pressing whereas seed PA increase progressively through the maceration phase $(159,160)$. Seed PA extraction is favored and accelerated by the presence of alcohol $(157,158,161)$. Overall, extended maceration time appears to greatly influence PA content of wine. Skin contact of 3 to 4 weeks or longer appears to leach the largest amount of PA into wine; however, consideration of shorter maceration times for preservation of anthocyanins must also be considered $(157,162,163)$.

Often winemakers apply temperature variations in the maceration process, which can affect the finished wine. The most commonly used methods are heating or cold soaking at the end of maceration. Heat treatment, like the addition of pectolytic enzymes, is intentionally applied to damage grape hypodermal cell walls and membranes to aid in extraction of phenolic compounds (164). Heat, in combination with aqueous ethanol increases this effect, until the point at which ethanol begins to boil $\left(78.5^{\circ} \mathrm{C}\right)$, or it begins to oxidize or degrade the desired compounds $(165,166)$. Reports vary, with some showing an increase in anthocyanin levels via this method, but the majority reveal a destructive effect on the phenolic chemicals (167).

Cold soak treatment occurs when grape berries are mashed, cooled to a low temperature and then kept for several days. This is typically achieved by cooling the fermentation tank, placing the holding vessel in a cool, ambient environment, or by applying dry ice, characteristically achieving a temperature below $10^{\circ} \mathrm{C}$ $(164,165)$. In a study assessing several popular red varietals, including Cabernet Sauvignon, Malbec, and Merlot, the coldsoak technique enhanced the extraction of anthocyanins, but inhibited the extraction of PA, which with controlled application, could be valuable in balancing astringency and bitterness (168). 
Adjusting the duration of cold soak (0, 1, 4, 7, and 10 days) impacts the extraction of anthocyanins, determining that extraction increases in all cases at least initially, but beyond the 5 th day of cold-soak treatment, anthocyanins begin to react with other compounds, thus lowering overall concentration (169). This effect, however, is dependent on the grape variety and its associated physical properties; Tannat grapes, for instance, have hardy cell walls and cold soaking combined with extended fermentation significantly increases anthocyanin content in wine produced from this grape variety (56).

During the fermentation process levels of sugar steadily decrease as the yeast metabolizes it, producing alcohol in the process (170). The presence or addition of sugar can be detrimental to anthocyanin levels, as it promotes its degradation (171). However, high levels of alcohol can degrade anthocyanins as well (172).

Finally, fining agents can be used for a number of reasons, including clarification, eradication of off-aromas, and reduction of bitterness or astringency to provide a softer wine and appeal to a wide audience of wine drinkers. Fining techniques include agents that can bind and filter certain components of the wine, and include egg albumen, casein, bentonite, elatine, skim milk, carbon, activated carbon, Isinglass, and Polyvinylpolypyrrolidone (PVPP) (173). While winemakers often rely of fining to stylize or achieve a desired sensorial affect, overutilization of fining can remove anthocyanins, PA and other phenols, often leaving a less pigmented wine (174). The minimization or avoidance of fining will generally yield wine with generally higher levels of polyphenols, enhancing its positive health influence.

\section{Wine Aging: (Wood Tannins)}

Although not the focus of this discussion, wine aging, specifically in contact with wood, should be addressed due to its effect on the chemical composition of wines. Wine is often aged within wood barrels, or with the introduction of staves and chips. When barrels are utilized, wines are placed, most commonly, in American oak (Q. Alba) or French oak (Q. robur, Q. petraea) barrels to age and undergo gentle oxidation, which results in decreased astringency and concentrates color and stabilization of pigment structures (175). These elements allow soluble oak extracts to diffuse into the wine while contributing to sensorial characteristics within the wine. However, much like the skins, seeds, and stems of wine, wood used for aging has naturally occurring tannins that can leach into the aging wine. Of note, excessive aging in the bottle, on the other hand, can result in breakdown of anthocyanin. Thus younger wines would be expected to have elevated levels of phenolic chemicals (176).

Ellagitannins, a type of hydrolysable tannin, different from condensed tannins or PA in grapes, are concentrated in oak bark. As an extract into finished wine, they are associated with bitterness and astringency, a signal of their use in nature to deter potential predators (177).

The effect and degree of toasting of oak barrels, chips and staves also influences both organoleptic profiles and polyphenol content in wines. Toasting is a technique in which a barrel is fired, and in which wood tannins are mellowed and raw oak flavors are muted. Toasting is often considered at three temperatureregulated levels, including light (LT), medium (MT), and heavy (HT), and at these varying levels, wood lignans, hemicelluloses and cellulose structures undergo changes effecting permeability that ultimately influence the wines aged within them (178). LT yields the highest levels of ellagitannins. On the other hand, heavier toasting disrupts lignin bonds, which results in greater concentrations of vanillin, syringaldehyde, guaiacol, and furfurals, important for organoleptic properties of the wine, in addition to enhancing the abundance of beneficial compounds in finished wine. In vivo and in vitro studies show antitumor, antiinvasive, antimetastatic and antiangiogenic qualities of vanillin, and its therapeutic potential in cancer prevention and treatment is of continued interest in the research community (179).

Barrels from oak species are the most common cooperage technology, or fermentation vessel, for both red and white wine and the nearly exclusive use of oak is regulated by OIV rules and EU regulations; however, other non-oak species including cherry, chestnut, false acacia, and ash have also been applied beyond the EU $(180,181)$. The literature suggests that while oak lends most meaningfully to sensorial and organoleptic appeal, polyphenols and lignin derivatives are significantly more concentrated in ash, chestnut and cherry, where they are imparted on wine in a much shorter timeframe, as compared with oak (181). Similar to lignans, lignins, a complex, non-carbohydrate aromatic polymer found in all woods, continue to be a heavily researched area with high potential for applications in the treatment of obesity, cancer, thrombosis, viral infections and diabetes (Figure 2) (59, $179,182)$. Research on oak and other wood species constituents and wine aging processes supports the transmission of additional beneficial compounds into finished wine.

\section{CONCLUSIONS}

While cultivar contributes meaningfully to the level of anthocyanins and PA in wines, the influence of other viticulture practices is not insignificant. We hypothesize that wines produced from grapes cultivated between steady daily temperatures at $15-25^{\circ} \mathrm{C}$ with moderate sun exposure from flowering to harvest, lower vine-water status, resulting either from lower precipitation, and irrigation practices or more permeable soil types, will produce a wine with a higher concentration of anthocyanins and PA. The limitation of fertilizers in a soil rich with mineral deposits can also be considered in order to activate abiotic stress response. Furthermore, winemaker manipulation including maceration of red wines for 3 to 4 weeks appears to result in the greatest optimization of overall healthy phenols. Fining practices should be avoided or limited in use given their effect of decreasing phenolic compounds. Aging wine in oak may enhance tannin content along with lignan, lignin and other potentially healthy polyphenol content, however, wines aged excessively may experience a breakdown of anthocyanins. Wines consumed that follow these criteria are hypothesized to have a different, beneficial effect upon health. 
All studies that have assessed the associations between wine consumption and health have viewed wine as a single entity. The above information provides significant evidence that wine consumption should not be viewed as a binary entity, and the multitude of growing and production conditions, including temperature, water availability, soil type, maceration, and aging can create a remarkably dissimilar final product. Based on the available studies, two types of wine with vastly different chemical and macronutrient profiles can be produced based

\section{REFERENCES}

1. 2018 World Vitiviniculture Situation. OIV Statistical Report on World Vitiviniculture. Available online at: http://www.oiv.int/public/medias/ 6371/oiv-statistical-report-on-world-vitiviniculture-2018.pdf (accessed December 30, 2018).

2. Vecchio R, Decordi G, Grésillon L, Gugenberger C, Mahéo M, Jourjon F. European consumers' perception of moderate wine consumption on health. Wine Econ Policy. (2017) 6:14-22. doi: 10.1016/J.WEP.2017.04.001

3. Center for Behavioral Health Statistics and Quality. Results From the 2016 National Survery on Drug Use and Health: Detailed Tables. Available online at: https://www.samhsa.gov/data/sites/default/files/NSDUH-DetTabs-2016/ NSDUH-DetTabs-2016.pdf (accessed December 9, 2018).

4. Bagnardi V, Rota M, Botteri E, Tramacere I, Islami F, Fedirko V, et al. Alcohol consumption and site-specific cancer risk: a comprehensive dose-response meta-analysis. Br J Cancer. (2015) 112:580-93. doi: 10.1038/bjc.2014.579

5. Bagnardi V, Rota M, Botteri E, Tramacere I, Islami F, Fedirko V, et al. Light alcohol drinking and cancer: a meta-analysis. Ann Oncol. (2013) 24:301-8. doi: 10.1093/annonc/mds337

6. Connor J. Alcohol consumption as a cause of cancer. Addiction. (2017) 112:222-8. doi: 10.1111/add.13477

7. Hamajima N, Hirose K, Tajima K, Rohan T, Calle EE, Heath CW, et al. Alcohol, tobacco and breast cancer - collaborative reanalysis of individual data from 53 epidemiological studies, including 58515 women with breast cancer and 95067 women without the disease. Br J Cancer. (2002) 87:123445. doi: $10.1038 /$ sj.bjc. 6600596

8. Hashibe M, Brennan P, Chuang S-C, Boccia S, Castellsague X, Chen C, et al. Interaction between tobacco and alcohol use and the risk of head and neck cancer: pooled analysis in the international head and neck cancer epidemiology consortium. Cancer Epidemiol Biomarkers Prev. (2009) 18:541-50. doi: 10.1158/1055-9965.EPI-08-0347

9. Allen NE, Beral V, Casabonne D, Kan SW, Reeves GK, Brown A, et al. Moderate alcohol intake and cancer incidence in women. JNCI J Natl Cancer Inst. (2009) 101:296-305. doi: 10.1093/jnci/djn514

10. Boschloo L, Vogelzangs N, Smit JH, van den Brink W, Veltman DJ, Beekman ATF, et al. Comorbidity and risk indicators for alcohol use disorders among persons with anxiety and/or depressive disorders: findings from the Netherlands Study of Depression and Anxiety (NESDA). J Affect Disord. (2011) 131:233-42. doi: 10.1016/J.JAD.2010.12.014

11. Klarich DS, Brasser SM, Hong MY. Moderate alcohol consumption and colorectal cancer risk. Alcohol Clin Exp Res. (2015) 39:1280-91. doi: $10.1111 /$ acer.12778

12. Grønbaek M, Becker U, Johansen D, Gottschau A, Schnohr P, Hein $\mathrm{HO}$, et al. Type of alcohol consumed and mortality from all causes, coronary heart disease, and cancer. Ann Intern Med. (2000) 133:411-9. doi: 10.7326/0003-4819-133-6-200009190-00008

13. Vieira AR, Abar L, Chan DSM, Vingeliene S, Polemiti E, Stevens C, et al. Foods and beverages and colorectal cancer risk: a systematic review and meta-analysis of cohort studies, an update of the evidence of the WCRF-AICR Continuous Update Project. Ann Oncol. (2017) 28:1788-802. doi: 10.1093/annonc/mdx171

14. Xu W, Fan H, Han Z, Liu Y, Wang Y, Ge Z. Wine consumption and colorectal cancer risk: a meta-analysis of observational studies. Eur J Cancer Prev. (2018) 28:151-8. doi: 10.1097/CEJ.0000000000000444 on the type of grape, growing conditions, and production methods, and differing health results are to be expected after the consumption of these wines. Future studies should incorporate these differences.

\section{AUTHOR CONTRIBUTIONS}

Both CC and AK-C contributed in the design, data gathering, data synthesis, writing, and editing of the manuscript.

15. Phipps AI, Robinson JR, Campbell PT, Win AK, Figueiredo JC, Lindor NM, et al. Prediagnostic alcohol consumption and colorectal cancer survival: the colon cancer family registry. Cancer. (2017) 123:1035-43. doi: $10.1002 / \mathrm{cncr} .30446$

16. Purohit V, Bode JC, Bode C, Brenner DA, Choudhry MA, Hamilton F, et al. Alcohol, intestinal bacterial growth, intestinal permeability to endotoxin, and medical consequences: summary of a symposium. Alcohol. (2008) 42:349-61. doi: 10.1016/j.alcohol.2008.03.131

17. Lambert B, He SM. DNA and chromosome damage induced by acetaldehyde in human lymphocytes in vitro. Ann N Y Acad Sci. (1988) 534:369-76.

18. Clemons M, Goss P. Estrogen and the risk of breast cancer. $N$ Engl J Med. (2001) 344:276-85. doi: 10.1056/NEJM200101253440407

19. Haskins CP, Henderson G, Champ CE. Meat, eggs, full-fat dairy, and nutritional boogeymen: does the way in which animals are raised affect health differently in humans? Crit Rev Food Sci Nutr. (2018). doi: 10.1080/10408398.2018.1465888. [Epub ahead of print].

20. Lü J-M, Lin PH, Yao Q, Chen C. Chemical and molecular mechanisms of antioxidants: experimental approaches and model systems. J Cell Mol Med. (2010) 14:840-60. doi: 10.1111/j.1582-4934.2009.00897.x

21. Zhu Z, Jiang W, McGinley JN, Thompson HJ. 2-deoxyglucose as an energy restriction mimetic agent: effects on mammary carcinogenesis and on mammary tumor cell growth in vitro. Cancer Res. (2005) 65:7023-30. doi: 10.1158/0008-5472.CAN-05-0453

22. Michel J, Jourdes M, Silva MA, Giordanengo T, Mourey N, Teissedre P-L. Impact of concentration of ellagitannins in oak wood on their levels and organoleptic influence in red wine. J Agric Food Chem. (2011) 59:5677-83. doi: $10.1021 /$ jf200275w

23. Lee J-H, Johnson JV, Talcott ST. Identification of ellagic acid conjugates and other polyphenolics in muscadine grapes by HPLC-ESI-MS. J Agric Food Chem. (2005) 53:6003-10. doi: 10.1021/jf050468r

24. Guo C, Cao G, Sofic E, Prior RL. High-performance liquid chromatography coupled with coulometric array detection of electroactive components in fruits and vegetables: relationship to oxygen radical absorbance capacity. $J$ Agric Food Chem. (1997) 45:1787-96.

25. Rice-evans CA, Miller NJ, Bolwell PG, Bramley PM, Pridham JB. The relative antioxidant activities of plant-derived polyphenolic flavonoids. Free Radic Res. (1995) 22:375-83. doi: 10.3109/10715769509145649

26. Surh Y-J, Hurh Y-J, Kang J-Y, Lee E, Kong G, Lee SJ. Resveratrol, an antioxidant present in red wine, induces apoptosis in human promyelocytic leukemia (HL-60) cells. Cancer Lett. (1999) 140:1-10. doi: 10.1016/S0304-3835(99)00039-7

27. Cao G, Russell RM, Lischner N, Prior RL. Serum antioxidant capacity is increased by consumption of strawberries, spinach, red wine or vitamin C in elderly women. J Nutr. (1998) 128:2383-90. doi: 10.1093/jn/128.12.2383

28. Paiva SA, Yeum K-J, Cao G, Prior RL, Russell RM. Postprandial plasma carotenoid responses following consumption of strawberries, red wine, vitamin C or spinach by elderly women. J Nutr. (1998) 128:2391-4. doi: $10.1093 /$ jn/128.12.2391

29. Greenrod W, Fenech M. The principal phenolic and alcoholic components of wine protect human lymphocytes against hydrogen peroxide- and ionizing radiation-induced DNA damage in vitro. Mutagenesis. (2003) 18:119-26. doi: 10.1093/mutage/18.2.119

30. Giovannelli L, Testa G, De Filippo C, Cheynier V, Clifford MN, Dolara P. Effect of complex polyphenols and tannins from red wine on DNA 
oxidative damage of rat colon mucosa in vivo. Eur J Nutr. (2000) 39:207-12. doi: 10.1007/s003940070013

31. Micallef M, Lexis L, Lewandowski P. Red wine consumption increases antioxidant status and decreases oxidative stress in the circulation of both young and old humans. Nutr J. (2007) 6:27. doi: 10.1186/1475-2891-6-27

32. Houghton CA, Fassett RG, Coombes JS. Sulforaphane: translational research from laboratory bench to clinic. Nutr Rev. (2013) 71:709-26. doi: $10.1111 /$ nure. 12060

33. Venugopal R, Jaiswal AK. Nrf1 and Nrf2 positively and c-Fos and Fra1 negatively regulate the human antioxidant response element-mediated expression of NAD(P)H:quinone oxidoreductasel gene. Proc Natl Acad Sci USA. (1996) 93:14960-5.

34. Jang M, Cai L, Udeani GO, Slowing KV, Thomas CF, Beecher $\mathrm{CW}$, et al. Cancer chemopreventive activity of resveratrol, a natural product derived from grapes. Science. (1997) 275:218-20. doi: 10.1126/SCIENCE.275.5297.218

35. D'Archivio M, Filesi C, Varì R, Scazzocchio B, Masella R. Bioavailability of the polyphenols: status and controversies. Int J Mol Sci. (2010) 11:1321-42. doi: 10.3390/ijms11041321

36. Modun D, Music I, Vukovic J, Brizic I, Katalinic V, Obad A, et al. The increase in human plasma antioxidant capacity after red wine consumption is due to both plasma urate and wine polyphenols. Atherosclerosis. (2008) 197:250-6. doi: 10.1016/j.atherosclerosis.2007.04.002

37. Boban M, Modun D, Music I, Vukovic J, Brizic I, Salamunic I, et al. Red wine induced modulation of vascular function: separating the role of polyphenols, ethanol, and urates. J Cardiovasc Pharmacol. (2006) 47:695701. doi: 10.1097/01.fjc.0000211762.06271.ce

38. Abu-Amsha Caccetta R, Burke V, Mori TA, Beilin LJ, Puddey IB, Croft $\mathrm{KD}$. Red wine polyphenols, in the absence of alcohol, reduce lipid peroxidative stress in smoking subjects. Free Radic Biol Med. (2001) 30:63642. doi: 10.1016/S0891-5849(00)00497-4

39. Quideau S, Jourdes M, Saucier C, Glories Y, Pardon P, Baudry C. DNA topoisomerase inhibitor acutissimin A and other flavano-ellagitannins in red wine. Angew Chem Int Ed. (2003) 42:6012-14. doi: 10.1002/anie.200352089

40. Snopek L, Mlcek J, Sochorova L, Baron M, Hlavacova I, Jurikova T, et al. Contribution of red wine consumption to human health protection. Molecules. (2018) 23:1684. doi: 10.3390/molecules23071684

41. Adlercreutz H. Lignans and human health. Crit Rev Clin Lab Sci. (2007) 44:483-525. doi: 10.1080/10408360701612942

42. Velentzis LS, Cantwell MM, Cardwell C, Keshtgar MR, Leathem AJ, Woodside J V. Lignans and breast cancer risk in pre- and post-menopausal women: meta-analyses of observational studies. Br J Cancer. (2009) 100:1492-8. doi: 10.1038/sj.bjc.6605003

43. Lin Y, Yngve A, Lagergren J, Lu Y. A dietary pattern rich in lignans, quercetin and resveratrol decreases the risk of oesophageal cancer. Br J Nutr. (2014) 112:2002-9. doi: 10.1017/S0007114514003055

44. Thrift AP, Pandeya N, Smith KJ, Mallitt K-A, Green AC, Webb PM, et al. Lifetime alcohol consumption and risk of Barrett's Esophagus. Am J Gastroenterol. (2011) 106:1220-30. doi: 10.1038/ajg.2011.89

45. Acuña-Avila PE, Vásquez-Murrieta MS, Franco Hernández MO, López-Cortéz MDS. Relationship between the elemental composition of grapeyards and bioactive compounds in the Cabernet Sauvignon grapes Vitis vinifera harvested in Mexico. Food Chem. (2016) 203:79-85. doi: 10.1016/j.foodchem.2016.02.031

46. Sato M, Ramarathnam N, Suzuki Y, Ohkubo T, Takeuchi M, Ochi H. Varietal differences in the phenolic content and superoxide radical scavenging potential of wines from different sources. J Agric Food Chem. (1996) 44:3741. doi: 10.1021/jf950190a

47. Cortell JM, Halbleib M, Gallagher AV, Righetti TL, Kennedy JA. Influence of vine vigor on grape (Vitis vinifera L. Cv. Pinot Noir) anthocyanins. 2. anthocyanins and pigmented polymers in wine. J Agric Food Chem. (2007) 55:6585-95. doi: 10.1021/jf070196n

48. Marè C, Aprile A, Roncaglia E, Tocci E, Corino LG, De Bellis $\mathrm{L}$, et al. Rootstock and soil induce transcriptome modulation of phenylpropanoid pathway in grape leaves. J Plant Interact. (2013) 8:33449. doi: 10.1080/17429145.2012.754958

49. Jordão AM, Correia AC. Relationship between antioxidant capacity, proanthocyanidin and anthocyanin content during grape maturation of touriga nacional and tinta roriz grape varieties. South Afr J Enol Vitic. (2016) 33, 214-24. doi: 10.21548/33-2-1121

50. Downey MO, Harvey JS, Robinson SP. Synthesis of flavonols and expression of flavonol synthase genes in the developing grape berries of Shiraz and Chardonnay (Vitis vinifera L.). Aust J Grape Wine Res. (2003) 9:110-21. doi: 10.1111/j.1755-0238.2003.tb00261.x

51. Adams DO. Phenolics and Ripening in Grape Berries. American Society of Enologists (2006). Available online at: http://www.ajevonline.org/content/ 57/3/249 (accessed December 29, 2018).

52. Cohen SD, Tarara JM, Gambetta GA, Matthews MA, Kennedy JA. Impact of diurnal temperature variation on grape berry development, proanthocyanidin accumulation, and the expression of flavonoid pathway genes. J Exp Bot. (2012) 63:2655-65. doi: 10.1093/jxb/err449

53. Cadot Y, Caillé S, Samson A, Barbeau G, Cheynier V. Sensory representation of typicality of Cabernet franc wines related to phenolic composition: impact of ripening stage and maceration time. Anal Chim Acta. (2012) 732:91-9. doi: 10.1016/J.ACA.2012.02.013

54. Jin Z-M, He J-J, Bi H-Q, Cui X-Y, Duan C-Q. Phenolic compound profiles in berry skins from nine red wine grape cultivars in northwest China. Molecules. (2009) 14:4922-35. doi: 10.3390/molecules 14124922

55. Granato D, Katayama FCU, de Castro IA. Phenolic composition of South American red wines classified according to their antioxidant activity, retail price and sensory quality. Food Chem. (2011) 129:366-73. doi: 10.1016/J.FOODCHEM.2011.04.085

56. Gonz Alez-Neves G, An Favre G, Piccardo D, Gil G. Anthocyanin profile of young red wines of Tannat, Syrah and Merlot made using maceration enzymes and cold soak. Int J Food Sci Technol. (2015) 51:260-7. doi: $10.1111 /$ ijfs. 12958

57. Alcade-Eon C, Boido E, Carrau F, Dellacassa E, Rivas-Gonzalo JC. Pigment profiles in monovarietal wines produced in Uruguay. Am J Enol Vitic. (2006) 54:163-9.

58. Maurya DK, Devasagayam TPA. Antioxidant and prooxidant nature of hydroxycinnamic acid derivatives ferulic and caffeic acids. Food Chem Toxicol. (2010) 48:3369-73. doi: 10.1016/J.FCT.2010. 09.006

59. Alam MA, Subhan N, Hossain H, Hossain M, Reza HM, Rahman MM, et al. Hydroxycinnamic acid derivatives: a potential class of natural compounds for the management of lipid metabolism and obesity. Nutr Metab. (2016) 13:27. doi: 10.1186/s12986-016-0080-3

60. Esatbeyoglu T, Ewald P, Yasui Y, Yokokawa H, Wagner AE, Matsugo $S$, et al. Chemical characterization, free radical scavenging, and cellular antioxidant and anti-inflammatory properties of a stilbenoid-rich root extract of Vitis vinifera. Oxid Med Cell Longev. (2016) 2016:8591286. doi: $10.1155 / 2016 / 8591286$

61. Akinwumi BC, Bordun K-AM, Anderson HD. Biological activities of stilbenoids. Int J Mol Sci. (2018) 19:E792. doi: 10.3390/ijms19030792

62. Dvorakova M, Landa P. Anti-inflammatory activity of natural stilbenoids: a review. Pharmacol Res. (2017) 124:126-45. doi: 10.1016/j.phrs.2017.08.002

63. Sirerol JA, Rodríguez ML, Mena S, Asensi MA, Estrela JM, Ortega AL. Role of natural stilbenes in the prevention of cancer. Oxid Med Cell Longev. (2016) 2016:3128951. doi: 10.1155/2016/3128951

64. Ndiaye M, Philippe C, Mukhtar H, Ahmad N. The grape antioxidant resveratrol for skin disorders: promise, prospects, and challenges. Arch Biochem Biophys. (2011) 508:164-70. doi: 10.1016/j.abb.2010. 12.030

65. Sánchez-Maldonado AF, Schieber A, Gänzle MG. Structure-function relationships of the antibacterial activity of phenolic acids and their metabolism by lactic acid bacteria. J Appl Microbiol. (2011) 111:1176-84. doi: 10.1111/j.1365-2672.2011.05141.x

66. Juurlink BH, Azouz HJ, Aldalati AM, AlTinawi BM, Ganguly P. Hydroxybenzoic acid isomers and the cardiovascular system. Nutr J. (2014) 13:63. doi: 10.1186/1475-2891-13-63

67. Winter AN, Brenner MC, Punessen N, Snodgrass M, Byars C, Arora Y, et al. Comparison of the neuroprotective and anti-inflammatory effects of the anthocyanin metabolites, protocatechuic acid and 4-hydroxybenzoic acid. Oxid Med Cell Longev. (2017) 2017:6297080. doi: 10.1155/2017/6297080

68. Lekakis J, Rallidis LS, Andreadou I, Vamvakou G, Kazantzoglou G, Magiatis P, et al. Polyphenolic compounds from red grapes acutely improve 
endothelial function in patients with coronary heart disease. Eur J Cardiovasc Prev Rehabil. (2005) 12:596-600. doi: 10.1097/01.hjr.0000186622.52 863.93

69. Anand David AV, Arulmoli R, Parasuraman S. Overviews of biological importance of quercetin: a bioactive flavonoid. Pharmacogn Rev. (2016) 10:84-9. doi: 10.4103/0973-7847.194044

70. Warren CA, Paulhill KJ, Davidson LA, Lupton JR, Taddeo SS, Hong MY, et al. Quercetin may suppress rat aberrant crypt foci formation by suppressing inflammatory mediators that influence proliferation and apoptosis. J Nutr. (2009) 139:101-5. doi: 10.3945/jn.108.096271

71. Bahman AA, Abaza MSI, Khoushiash SI, Al-Attiyah RJ. Sequencedependent effect of sorafenib in combination with natural phenolic compounds on hepatic cancer cells and the possible mechanism of action. Int J Mol Med. (2018) 42:1695-715. doi: 10.3892/ijmm.2018. 3725

72. Luo H, Rankin GO, Juliano N, Jiang B-H, Chen YC. Kaempferol inhibits VEGF expression and in vitro angiogenesis through a novel ERK-NFkB-cMyc-p21 pathway. Food Chem. (2012) 130:321-8. doi: 10.1016/j.foodchem.2011.07.045

73. Cortes JR, Perez-G M, Rivas MD, Zamorano J. Kaempferol inhibits IL-4induced STAT6 activation by specifically targeting JAK3. J Immunol. (2007) 179:3881-7. doi: 10.4049/jimmunol.179.6.3881

74. Stephens PJ, Tarpey PS, Davies H, Van Loo P, Greenman C, Wedge DC, et al. The landscape of cancer genes and mutational processes in breast cancer. Nature. (2012) 486:400-4. doi: 10.1038/nature 11017

75. Chen AY, Chen YC. A review of the dietary flavonoid, kaempferol on human health and cancer chemoprevention. Food Chem. (2013) 138:2099-107. doi: 10.1016/j.foodchem.2012.11.139

76. Phromnoi K, Yodkeeree S, Anuchapreeda S, Limtrakul P. Inhibition of MMP-3 activity and invasion of the MDA-MB-231 human invasive breast carcinoma cell line by bioflavonoids. Acta Pharmacol Sin. (2009) 30:1169-76. doi: 10.1038/aps.2009.107

77. Semwal DK, Semwal RB, Combrinck S, Viljoen A. Myricetin: a dietary molecule with diverse biological activities. Nutrients. (2016) 8:90. doi: $10.3390 /$ nu 8020090

78. Ong KC, Khoo HE. Insulinomimetic effects of myricetin on lipogenesis and glucose transport in rat adipocytes but not glucose transport translocation. Biochem Pharmacol. (1996) 51:423-9.

79. Li Y, Ding Y. Minireview: therapeutic potential of myricetin in diabetes mellitus. Food Sci Hum Wellness. (2012) 1:19-25. doi: 10.1016/J.FSHW.2012.08.002

80. Meiers S, Kemény M, Weyand U, Gastpar R, von Angerer E, Marko D. The anthocyanidins cyanidin and delphinidin are potent inhibitors of the epidermal growth-factor receptor. J Agric Food Chem. (2001) 49:958-62. doi: 10.1021/JF0009100

81. Yun J-M, Afaq F, Khan N, Mukhtar H. Delphinidin, an anthocyanidin in pigmented fruits and vegetables, induces apoptosis and cell cycle arrest in human colon cancer HCT116 cells. Mol Carcinog. (2009) 48:260-70. doi: $10.1002 / \mathrm{mc} .20477$

82. Moriwaki S, Suzuki K, Muramatsu M, Nomura A, Inoue F, Into T, et al. Delphinidin, one of the major anthocyanidins, prevents bone loss through the inhibition of excessive osteoclastogenesis in osteoporosis model mice. PLoS ONE. (2014) 9:e97177. doi: 10.1371/journal.pone.0097177

83. Ramos P, Herrera R, Moya-Leon MA. Handbook of anthocyanins. anthocyanins: food sources and benefits to consumer's health. In: Warner LM, editor. Handbook of Anthocyanins. Hauppauge, NY: Nova Science Publishrs (2014). p. 373-394.

84. Queipo-Ortuño MI, Boto-Ordóñez M, Murri M, Gomez-Zumaquero JM, Clemente-Postigo M, Estruch R, et al. Influence of red wine polyphenols and ethanol on the gut microbiota ecology and biochemical biomarkers. Am J Clin Nutr. (2012) 95:1323-34. doi: 10.3945/ajcn.111.027847

85. Huang W, Zhu Y, Li C, Sui Z, Min W. Effect of blueberry anthocyanins malvidin and glycosides on the antioxidant properties in endothelial cells. Oxid Med Cell Longev. (2016) 2016:1-10. doi: 10.1155/2016/1591803

86. Matsunaga N, Imai S, Inokuchi Y, Shimazawa M, Yokota S, Araki Y, et al. Bilberry and its main constituents have neuroprotective effects against retinal neuronal damage in vitro and in vivo. Mol Nutr Food Res. (2009) 53:869-77. doi: $10.1002 / \mathrm{mnfr} .200800394$
87. Rózanska D, Regulska-Ilow B. The significance of anthocyanins in the prevention and treatment of type 2 diabetes. Adv Clin Exp Med. (2018) 27:135-42. doi: 10.17219/acem/64983

88. Kwon JY, Lee KW, Hur HJ, Lee HJ. Peonidin inhibits phorbol-esterinduced COX-2 expression and transformation in JB6 P+ cells by blocking phosphorylation of ERK-1 and-2. Ann N Y Acad Sci. (2007) 1095:513-20. doi: 10.1196/annals.1397.055

89. Mangels DR, Mohler ER. Catechins as potential mediators of cardiovascular health. Arterioscler Thromb Vasc Biol. (2017) 37:757-63. doi: 10.1161/ATVBAHA.117.309048

90. Ide K, Matsuoka N, Yamada H, Furushima D, Kawakami K. Effects of tea catechins on Alzheimer's disease: recent updates and perspectives. Molecules. (2018) 23:E2357. doi: 10.3390/molecules23092357

91. Morrison M, van der Heijden R, Heeringa P, Kaijzel E, Verschuren L, Blomhoff R, et al. Epicatechin attenuates atherosclerosis and exerts anti-inflammatory effects on diet-induced humanCRP and NFKB in vivo. Atherosclerosis. (2014) 233:149-56. doi: 10.1016/j.atherosclerosis.2013.12.027

92. Huang L, Pan C, Wang L, Ding L, Guo K, Wang H, et al. Protective effects of grape seed proanthocyanidins on cardiovascular remodeling in DOCA-salt hypertension rats. J Nutr Biochem. (2015) 26:841-9. doi: 10.1016/j.jnutbio.2015.03.007

93. Bagchi D, Garg A, Krohn RL, Bagchi M, Bagchi DJ, Balmoori J, et al. Protective effects of grape seed proanthocyanidins and selected antioxidants against TPA-induced hepatic and brain lipid peroxidation and DNA fragmentation, and peritoneal macrophage activation in mice. Gen Pharmacol. (1998) 30:771-6.

94. Bagchi D, Swaroop A, Preuss HG, Bagchi M. Free radical scavenging, antioxidant and cancer chemoprevention by grape seed proanthocyanidin: an overview. Mutat Res Mol Mech Mutagen. (2014) 768:69-73. doi: 10.1016/j.mrfmmm.2014.04.004

95. Fujii W, Toda K, Kawaguchi K, Kawahara S, Katoh M, Hattori Y, et al. Syntheses of prodelphinidin B3 and C2, and their antitumor activities through cell cycle arrest and caspase-3 activation. Tetrahedron. (2013) 69:3543-50. doi: 10.1016/j.tet.2013.02.087

96. Nandakumar V, Singh T, Katiyar SK. Multi-targeted prevention and therapy of cancer by proanthocyanidins. Cancer Lett. (2008) 269:378-87. doi: 10.1016/j.canlet.2008.03.049

97. Xia E-Q, Deng G-F, Guo Y-J, Li H-B. Biological activities of polyphenols from grapes. Int J Mol Sci. (2010) 11:622-46. doi: 10.3390/ijms11020622

98. Ma ZF, Zhang H. Phytochemical constituents, health benefits, and industrial applications of grape seeds: a mini-review. Antioxidants. (2017) 6:E71. doi: 10.3390/antiox6030071

99. Lila MA. Anthocyanins and human health: an in vitro investigative approach. J Biomed Biotechnol. (2004) 2004:306-13. doi: 10.1155/S111072430 $440401 X$

100. Mittal A, Elmets CA, Katiyar SK. Dietary feeding of proanthocyanidins from grape seeds prevents photocarcinogenesis in SKH-1 hairless mice: relationship to decreased fat and lipid peroxidation. Carcinogenesis. (2003) 24:1379-88. doi: 10.1093/carcin/bgg095

101. Mantena SK, Baliga MS, Katiyar SK. Grape seed proanthocyanidins induce apoptosis and inhibit metastasis of highly metastatic breast carcinoma cells. Carcinogenesis. (2005) 27:1682-91. doi: 10.1093/carcin/bgl030

102. Singh RP, Tyagi AK, Dhanalakshmi S, Agarwal R, Agarwal C. Grape seed extract inhibits advanced human prostate tumor growth and angiogenesis and upregulates insulin-like growth factor binding protein-3. Int J Cancer. (2004) 108:733-40. doi: 10.1002/ijc.11620

103. Seguin G. 'Terroirs' and pedology of wine growing. Experientia. (1986) 42:861-73. doi: 10.1007/BF01941763

104. Hannah L, Roehrdanz PR, Ikegami M, Shepard AV, Shaw MR, Tabor G, et al. Climate change, wine, and conservation. Proc Natl Acad Sci USA. (2013) 110:6907-12. doi: 10.1073/pnas.1210127110

105. Spayd S, Tarara J, Mee D, Ferguson J. Separation of Sunlight and Temperature Effects on the Composition of Vitis vinifera cv. Merlot Berries. American Society of Enologists (2002). Available online at: http://www.ajevonline.org/ content/53/3/171 (accessed December 29, 2018).

106. Dokoozlian J, Ebisuda N, Ebisuda N. Sunlight exposure and temperature effects on berry growth and composition of cabernet sauvignon and grenache in the central San Joaquin valley of California. Am J Enol Vitic. (2001) 52:1-7. 
107. Mori K, Sugaya S, Gemma H. Decreased anthocyanin biosynthesis in grape berries grown under elevated night temperature condition. Sci Hortic. (2005) 105:319-30. doi: 10.1016/J.SCIENTA.2005.01.032

108. Artem V, Antoce AO, Ranca A, Nechita A, Enache L, Postolache E. The influence of terroir on phenolic composition of red grapes. Bull Univ Agric Sci Vet Med Cluj-Napoca Hortic. (2016) 73:109. doi: 10.15835/buasvmcn-hort:12173

109. Matus JT, Loyola R, Vega A, Peña-Neira A, Bordeu E, Arce-Johnson P, et al. Post-veraison sunlight exposure induces MYB-mediated transcriptional regulation of anthocyanin and flavonol synthesis in berry skins of Vitis vinifera. J Exp Bot. (2009) 60:853-67. doi: 10.1093/jxb/ern336

110. Cohen SD, Tarara JM, Kennedy JA. Assessing the impact of temperature on grape phenolic metabolism. Anal Chim Acta. (2008) 621:57-67. doi: 10.1016/J.ACA.2007.11.029

111. Mori K, Goto-Yamamoto N, Kitayama M, Hashizume K. Loss of anthocyanins in red-wine grape under high temperature. J Exp Bot. (2007) 58:1935-45. doi: 10.1093/jxb/erm055

112. Gaiotti F, Pastore C, Filippetti I, Lovat L, Belfiore N, Tomasi D. Low night temperature at veraison enhances the accumulation of anthocyanins in Corvina grapes (Vitis Vinifera L.). Sci Rep. (2018) 8:8719. doi: 10.1038/s41598-018-26921-4

113. Guan L, Li J-H, Fan P-G, Li S-H, Fang J-B, Dai Z-W, et al. Regulation of anthocyanin biosynthesis in tissues of a teinturier grape cultivar under sunlight exclusion. Am J Enol Vitic. (2014) 65:363-74. doi: 10.5344/ajev.2014.14029

114. Chorti E, Guidoni S, Ferrandino A, Novello V. Effect of different cluster sunlight exposure levels on ripening and anthocyanin accumulation in nebbiolo grapes. Am J Enol Vitic. (2010) 61:23-30.

115. Fernández K, Kennedy JA, Agosin E. Characterization of Vitis vinifera L. Cv. carménère grape and wine proanthocyanidins. J Agric Food Chem. (2007) 55:3675-80. doi: 10.1021/jf063232b

116. Downey MO, Harvey JS, Robinson SP. The effect of bunch shading on berry development and flavonoid accumulation in Shiraz grapes. Aust J Grape Wine Res. (2008) 10:55-73. doi: 10.1111/j.1755-0238.2004.tb00008.x

117. Ristic R, Downey M, Iland P, Bindon K, Frances L, Herderich M, et. al. Exclusion of sunlight from Shiraz grapes alters wine colour, tannin and sensory properties. Austr J Grape Wine Res. (2007) 13:53-65. doi: 10.1111/j.1755-0238.2007.tb00235.x

118. Asproudi A, Piano F, Anselmi G, Di Stefano R, Bertolone E, Borsa D. Proanthocyanidin composition and evolution during grape ripening as affected by variety: Nebbiolo and Barbera cv. J Int Sci Vign Vin. (2015) 49:59-69. doi: 10.20870/oeno-one.2015.49.1.93

119. Lee J. Light exclusion influence on grape anthocyanin. Heliyon. (2017) 3:e00243. doi: 10.1016/J.HELIYON.2017.E00243

120. Mirás-Avalos JM, Intrigliolo DS. Grape composition under abiotic constrains: water stress and salinity. Front Plant Sci. (2017) 8:851. doi: 10.3389/fpls.2017.00851

121. Salinari F, Giosue S, Tubiello N, Rettori A, Rossi V, Spanna F, et al. Downy mildew (Plasmopara viticola) epidemics on grapevine under climate change. Glob Chang Biol. (2006) 12:1299-307. doi: 10.1111/j.1365-2486.2006.01175.x

122. Considine J, Kriedemann P. Fruit splitting in grapes: determination of the critical turgor pressure. Aust J Agric Res. (1972) 23:17. doi: 10.1071/AR9720017

123. Rajha HN, El Darra N, El Kantar S, Hobaika Z, Louka N, Maroun RG. A Comparative study of the phenolic and technological maturities of red grapes grown in Lebanon. Antioxidants. (2017) 6:8. doi: 10.3390/antiox6010008

124. Cheng G, He Y-N, Yue T-X, Wang J, Zhang Z-W. Effects of climatic conditions and soil properties on cabernet sauvignon berry growth and anthocyanin profiles. Molecules. (2014) 19:13683-703. doi: 10.3390/molecules190913683

125. Castellarin SD, Matthews MA, Di Gaspero G, Gambetta GA. Water deficits accelerate ripening and induce changes in gene expression regulating flavonoid biosynthesis in grape berries. Planta. (2007) 227:101-12. doi: 10.1007/s00425-007-0598-8

126. Ollé D, Guiraud JL, Souquet JM, Terrier N, Ageorges A, Cheynier V, et al. Effect of pre- and post-veraison water deficit on proanthocyanidin and anthocyanin accumulation during Shiraz berry development. Aust J Grape Wine Res. (2011) 17:90-100. doi: 10.1111/j.1755-0238.2010.00121.x
127. Zarrouk O, Francisco R, Pinto-Marijuan M, Brossa R, Santos RR, Pinheiro $\mathrm{C}$, et al. Impact of irrigation regime on berry development and flavonoids composition in Aragonez (Syn. Tempranillo) grapevine. Agric Water Manag. (2012) 114:18-29. doi: 10.1016/J.AGWAT.2012.06.018

128. Casassa L, Keller M, Harbertson J. Regulated deficit irrigation alters anthocyanins, tannins and sensory properties of cabernet sauvignon grapes and wines. Molecules. (2015) 20:7820-44. doi: 10.3390/molecules20057820

129. Wang R, Sun Q, Chang Q. Soil types effect on grape and wine composition in helan mountain area of Ningxia. PLoS ONE. (2015) 10:e0116690. doi: 10.1371/journal.pone.0116690

130. Soubeyrand E, Basteau C, Hilbert G, van Leeuwen C, Delrot S, Gomès E. Nitrogen supply affects anthocyanin biosynthetic and regulatory genes in grapevine cv. Cabernet-Sauvignon berries. Phytochemistry. (2014) 103:3849. doi: 10.1016/j.phytochem.2014.03.024

131. Wheeler S, Pickering GJ. The effects of soil management techniques on grape and wine quality. In: Dris R, editor. Fruits. Growth, Nutrition and Quality. Helsinki: WFL Publisher (2006). p. 195-208.

132. Rogiers SY, Coetzee ZA, Walker RR, Deloire A, Tyerman SD. Potassium in the Grape (Vitis vinifera L.) berry: transport and function. Front Plant Sci. (2017) 8:1629. doi: 10.3389/fpls.2017.01629

133. Brunetto G, Bastos de Melo GW, Toselli M, Quartieri M, Tagliavini M. The role of mineral nutrition on yields and fruit quality in grapevine, pear and apple. Rev Bras Frutic. (2015) 37:1089-104. doi: 10.1590/0100-2945-103/15

134. Tesic D, Keller M, Hutton RJ. Influence of vineyard floor management practices on grapevine vegetative yield, and fruit composition. Am J Enol Vitic. (2007) 39:325-33.

135. Liang J, He J. Protective role of anthocyanins in plants under low nitrogen stress. Biochem Biophys Res Commun. (2018) 498:946-53. doi: 10.1016/j.bbrc.2018.03.087

136. Tränkner M, Tavakol E, Jákli B. Functioning of potassium and magnesium in photosynthesis, photosynthate translocation and photoprotection. Physiol Plant. (2018) 163:414-31. doi: 10.1111/ppl.12747

137. Ramos MC, Romero MP. Potassium uptake and redistribution in Cabernet Sauvignon and Syrah grape tissues and its relationship with grape quality parameters. J Sci Food Agric. (2017) 97:3268-77. doi: 10.1002/jsfa.8175

138. Ashley MK, Grant M, Grabov A. Plant responses to potassium deficiencies: a role for potassium transport proteins. J Exp Bot. (2006) 57:425-36. doi: 10.1093/jxb/erj034

139. Zhou S. Mitochondrial impairment in p53-deficient human cancer cells. Mutagenesis. (2003) 18:287-92. doi: 10.1093/mutage/18.3.287

140. Kodur S. Effects of juice $\mathrm{pH}$ and potassium on juice and wine quality, and regulation of potassium in grapevines through rootstocks (Vitis): a short review. Vitis Geilweilerhof. (2011). 50:1-6.

141. Mpelasoka BS, Schachtman DP, Treeby MT, Thomas MR. A review of potassium nutrition in grapevines with special emphasis on berry accumulation. Aust J Grape Wine Res. (2003) 9:154-68. doi: 10.1111/j.1755-0238.2003.tb00265.x

142. Zörb C, Senbayram M, Peiter E. Potassium in agriculture status and perspectives. J Plant Physiol. (2014) 171:656-69. doi: 10.1016/j.jplph.2013.08.008

143. Rice-Evans C, Miller N, Paganga G. Antioxidant properties of phenolic compounds. Trends Plant Sci. (1997) 2:152-9. doi: 10.1016/S1360-1385(97)01018-2

144. Lavid N, Schwartz A, Yarden O, Tel-Or E. The involvement of polyphenols and peroxidase activities in heavy-metal accumulation by epidermal glands of the waterlily (Nymphaeaceae). Planta. (2001) 212:323-31. doi: $10.1007 / \mathrm{s} 004250000400$

145. Pardo-García AI, Martínez-Gil AM, Cadahía E, Pardo F, Alonso GL, Salinas MR. Oak extract application to grapevines as a plant biostimulant to increase wine polyphenols. Food Res Int. (2013) 55:150-60. doi: 10.1016/j.foodres.2013.11.004

146. Yakhin OI, Lubyanov AA, Yakhin IA, Brown PH. Biostimulants in plant science: a global perspective. Front Plant Sci. (2016) 7:2049. doi: 10.3389/fpls.2016.02049

147. du Jardin P. Plant biostimulants: definition, concept, main categories and regulation. Sci Hortic. (2015) 196:3-14. doi: 10.1016/J.SCIENTA.2015.09.021

148. Bulgari R, Morgutti S, Cocetta G, Negrini N, Farris S, Calcante A, et al. Evaluation of borage extracts as potential biostimulant using a phenomic, 
agronomic, physiological, and biochemical approach. Front Plant Sci. (2017) 8:935. doi: 10.3389/fpls.2017.00935

149. Oszmianski J, Romeyer FM, Sapis JC, Macheix JJ. Grape seed phenolics: extraction as affected by some conditions occurring during wine processing. Am J Enol Vitic. (1986) 37:7-12.

150. Lukić I, Jedrejčić N, Ganić KK, Staver M, Peršurić Đ. Phenolic and aroma composition of white wines produced by prolonged maceration and maturation in wooden barrels. Food Technol Biotechnol. (2015) 53:407-18. doi: $10.17113 / \mathrm{ftb} \cdot 53.04 .15 .4144$

151. Darias-Martin JJ, Rodriguez O, Diaz E, Lamuela-Raventós RM. Effect of skin contact on the antioxidant phenolics in white wine. Food Chem. (2000) 71:483-7. doi: 10.1016/S0308-8146(00)00177-1

152. Revilla E, Alonso E, Kovac V. The content of catechins and procyanidins in grapes and wines as affected by agroecological factors and technological practices. ACS Sympos Ser. (1997) 661:69-80 doi: 10.1021/bk-1997-0661.ch007

153. González-Neves G, Gil G, Ferrer M, Charamelo D, Balado J, Bochicchio R, et al. Original article: prediction of the colour and polyphenolic composition of the young red wines from the phenolic potential of the grapes. Int J Food Sci Technol. (2010) 45:1843-51. doi: 10.1111/j.1365-2621.2010.02343.x

154. Casassa LF, Larsen RC, Beaver CW, Mireles MS, Keller M, Riley WR, et al. Impact of extended maceration and regulated deficit irrigation (RDI) in Cabernet Sauvignon wines: characterization of proanthocyanidin distribution, anthocyanin extraction, and chromatic properties. J Agric Food Chem. (2013) 61:6446-57. doi: 10.1021/jf400733u

155. Casassa LF, Harbertson JF. Extraction, evolution, and sensory impact of phenolic compounds during red wine maceration. Annu Rev Food Sci Technol. (2014) 5:83-109. doi: 10.1146/annurev-food-030713-092438

156. Gil M, Kontoudakis N, González E, Esteruelas M, Fort F, Canals $\mathrm{JM}$, et al. Influence of grape maturity and maceration length on color, polyphenolic composition, and polysaccharide content of Cabernet Sauvignon and Tempranillo wines. J Agric Food Chem. (2012) 60:7988-8001. doi: $10.1021 /$ jf302064n

157. Bautista-Ortín AB, Busse-Valverde N, Fernández-Fernández JI, GómezPlaza E, Gil-Muñoz R. The extraction kinetics of anthocyanins and proanthocyanidins from grape to wine in three different varieties. J Int Sci Vign Vin. (2016) 50, 91-100. doi: 10.20870/oeno-one.2016.50.2.781

158. Koyama K, Goto-Yamamoto N, Hashizume K. Influence of maceration temperature in red wine vinification on extraction of phenolics from berry skins and seeds of grape (Vitis vinifera). Biosci Biotechnol Biochem. (2007) 71:958-65. doi: 10.1271/bbb.60628

159. Cerpa-Calderón FK, Kennedy JA. Berry integrity and extraction of skin and seed proanthocyanidins during red wine fermentation. J Agric Food Chem. (2008) 56:9006-14. doi: 10.1021/jf801384v

160. Thorngate JH, Singleton VL. Localization of procyanidins in grape seeds. Am J Enol Vitic. (1994) 45:259-62.

161. Kocabey N, Yilmaztekin M, Hayaloglu AA. Effect of maceration duration on physicochemical characteristics, organic acid, phenolic compounds and antioxidant activity of red wine from Vitis vinifera L. Karaoglan. J Food Sci Technol. (2016) 53:3557-65. doi: 10.1007/s13197-016-2335-4

162. del Llaudy MC, Canals R, Canals JM, Zamora F. Influence of ripening stage and maceration length on the contribution of grape skins, seeds and stems to phenolic composition and astringency in wine-simulated macerations. Eur Food Res Technol. (2008) 226:337-44. doi: 10.1007/s00217-006-0542-3

163. Sacchi KL, Bisson LF, Adams DO. A review of the effect of winemaking techniques on phenolic extraction in red wines. Am J Enol Vitic. (2005) 56:197-206.

164. Ševcech J, Vicenová L, Furdíková K, Malík F. Influence of thermal treatment on polyphenol extraction of wine cv. André. Czech J Food Sci. (2014) 33:91-6. doi: 10.17221/286/2014-CJFS

165. Shi J, Yu J, Pohorly J, Young JC, Bryan M, Wu Y. Optimization of the extraction of polyphenols from grape seed meal by aqueous ethanol solution. J Food Agric Environ. (2003) 1:42-7.

166. He F, Liang N-N, Mu L, Pan Q-H, Wang J, Reeves MJ, et al. Anthocyanins and their variation in red wines I. monomeric anthocyanins and their color expression. Molecules. (2012) 17:1571-601. doi: 10.3390/molecules17021571
167. Casassa LF, Sar SE, Bolcato EA, Diaz-Sambueza MA, Catania AA, Fanzone ML, et al. Chemical and sensory effects of cold soak, whole cluster fermentation, and stem additions in pinot noir wines. Am J Enol Vitic. (2018) 70:ajev.2018.18014. doi: 10.5344/ajev.2018.18014

168. Panprivech S, Lerno L, Brenneman C, Block D, Oberholster A. Investigating the effect of cold soak duration on phenolic extraction during Cabernet Sauvignon fermentation. Molecules. (2015) 20:7974-89. doi: 10.3390/molecules20057974

169. Barwald G, Fischer A. Crabtree effect in aerobic fermentations using grape juice for the production of alcohol reduced wine. Biotechnol Lett. (1996) 18:1187-92. doi: 10.1007/BF00128590

170. Nikkhah E, Khayamy M, Heidari R, Jamee R. Effect of sugar treatment on stability of anthocyanin pigments in berries. J Biol Sci. (2007) 7:1412-17. doi: 10.3923/jbs.2007.1412.1417

171. Tseng K-C, Chang H-M, Wu JS-B. Degradation kinetics of anthocyanin in ethanolic solutions. J Food Process Preserv. (2006) 30:503-14. doi: 10.1111/j.1745-4549.2006.00083.x

172. Kalkan Yildirim H. Effects of fining agents on antioxidant capacity of red wines. J Inst Brew. (2011)117:55-60. doi: 10.1002/j.2050-0416.2011.tb00443.x

173. Stankovic S, Jovic S, Zivkovic J, Pavlovic R. Influence of age on red wine colour during fining with bentonite and gelatin. Int J Food Prop. (2012) 15:326-35. doi: 10.1080/10942912.2010.487625

174. Prida A, Puech J-L. Influence of geographical origin and botanical species on the content of extractives in American, French, and East European Oak Woods. J Agric Food Chem. (2006) 54:8115-26. doi: 10.1021/JF0616098

175. Monagas M, Bartolome B, Gomez-Cordoves C. Evolution of polyphenols in red wines from Vitis vinifera L. during aging in the bottle. Eur Food Res Technol. (2005) 220:331-40. doi: 10.1007/s00217-004-1109-9

176. Reyes Gonzalez-Centeno M, Teissedre P-L. Wine ageing in oak barrel: effect of toasting process. Agric Res Technol. (2018) 12:1-3. doi: 10.19080/ARTOAJ.2017.12.555847

177. Canas S. Phenolic composition and related properties of aged wine spirits: influence of barrel characteristics. a review. Beverages. (2017) 3:1-22. doi: 10.3390/beverages3040055

178. Setzer WN. Lignin-derived oak phenolics: a theoretical examination of additional potential health benefits of red wine. J Mol Model. (2011) 17:18415. doi: 10.1007/s00894-010-0893-3

179. Sanz M, Fernández de Simón B, Esteruelas E, Muñoz ÁM, Cadahía E, Hernández MT, et al. Polyphenols in red wine aged in acacia (Robinia pseudoacacia) and oak (Quercus petraea) wood barrels. Anal Chim Acta. (2012) 732:83-90. doi: 10.1016/J.ACA.2012.01.061

180. Fernández de Simón B, Esteruelas E, Muñoz AM, Cadahía E, Sanz M. Volatile compounds in acacia, chestnut, cherry, ash, and oak woods, with a view to their use in cooperage. J Agric Food Chem. (2009) 57:3217-27. doi: $10.1021 / \mathrm{jf} 803463 \mathrm{~h}$

181. Vinardell MP, Mitjans M. Lignins and their derivatives with beneficial effects on human health. Int J Mol Sci. (2017) 18:1219. doi: 10.3390/ijms18 061219

182. Patil S, Kaur M, Sharma HK. Effect of incorporation of mahua extract, fining agent and ageing on the quality characteristics of red wine. Indian J Microbiol. (2012) 52:406-10. doi: 10.1007/s12088-012-0249-z

Conflict of Interest Statement: CC receives compensation for nutrition books.

The remaining author declares that the research was conducted in the absence of any commercial or financial relationships that could be construed as a potential conflict of interest.

Copyright (c) 2019 Champ and Kundu-Champ. This is an open-access article distributed under the terms of the Creative Commons Attribution License (CC BY). The use, distribution or reproduction in other forums is permitted, provided the original author(s) and the copyright owner(s) are credited and that the original publication in this journal is cited, in accordance with accepted academic practice. No use, distribution or reproduction is permitted which does not comply with these terms. 